\title{
Etnomeditsiin ${ }^{1}$
}

Birgitte Rørbye

Teesid: Etnomeditsiinilised uuringud tähendavad erinevate inimeste ja rahvaste haiguste, tervise ja ravimisega seotud suhtumiste, põhimõtete ja käitumise jälgimist. Rahvaravitsejate tegevus ja nende poole pöördumine on säilinud tänapäevani, kuigi inimeste teadlikkus on kasvanud ja haridustase kõrgem. Siiski selgub, et hoolimata arstiabi kättesaadavusest leidub alati patsiente, kes pöörduvad üksnes rahvaravitsejate poole. Nende poole pöörduvad ka inimesed, kes pole saanud abi riiklikust meditsiinisüsteemist. Kõigele sellele viitavad rahvapärimuses käibivad haigus- ja ravijutud, mille peategelasteks on kas hea või halb patsient ning hea või halb ravija. Need, tihti stereotüüpsed rahvajutud, on peaaegu ainus materjal, mille põhjal saab teha järeldusi rahvaravitsejate poole pöördunud inimeste haiguskäitumise kohta. Kõige taga on aga asjaolu, et ühiskond hoiab kinni tervisemüüdist.

Märksõnad: arstiabi, etnomeditsiin, haiguskontseptsioon, haiguskäitumine, haigusjutt, patsient, rahvaravitsejad, ravijutud, tervisemüüt

\section{Etnomeditsiini põhimõisted}

Etnomeditsiinilised uuringud tähendavad erinevate inimeste ja rahvaste haiguste, tervise ja ravimisega seotud suhtumiste, põhimõtete ja käitumise jälgimist.

On enesestmõistetav, et igaüks teab, mida tähendab halb enesetunne: niisuguses olukorras kujundavad kõik arvamusi ja hoiakuid, teevad tähelepanekuid ja omandavad tõekspidamisi, mis on seotud haiguskogemusega. Seega võib öelda, et kõikidel inimestel on potentsiaalne teadmistepagas, mis on seotud haiguste, tervise ja paranemisega. See teadmiste hulk võib isiklike või välispidiste mõjutuste survel muutuda. Märkimisväärne osa neist teadmistest põhineb pärimusel, ülejäänud aspektid on aga individuaalsed. Teiste sõnadega - vastavaid teadmisi on jaganud paljud omavahel suhtlevad inimesed. 
Käesolevas etnomeditsiini põhitõdesid käsitlevas ülevaates kasutatakse peamiselt taani näiteid. Kuigi need on seotud teatud geograafilise piirkonnaga, ei tähenda see, et neid tuleks vaadelda taani kultuurile ainuomastena. Analoogilisi näiteid võib leida ka Norrast, Rootsist ja Soomest. Uurimuse eesmärk on eelkõige välja tuua etnomeditsiinile omaseid lähtekohti ja universaalseid aspekte. Seepärast on käesolevas töös toodud näited mõeldud illustreerivate ja dokumenteerivatena.

Rahvusvahelises mastaabis on ilmunud hulgaliselt etnomeditsiinialaseid töid (Lieban 1973: 1032 jj). Skandinaaviamaades on aga vastav uurimistöö olnud juhuslikum ja seotud rohkem arstiteaduse ajaloo või rahvapärimuse uurimisega, milles erilist tähelepanu on pööratud rahvauskumuste talletamisele (Rørbye 1978b: 311 jj). Artikkel oli esialgselt kirjutatud Skandinaaviamaade folkloristide koostööna aastatel 1975-1979 valminud raamatu Botare (Ravitsejad) tarbeks (Alver 1980). Siinavaldatu on selle kärbitud variant. Eriti puudutab see osi, mis käsitlevad patsientide tüüpe ja teadmiste levitamist. Olen püüdnud säilitada olulisimad tõekspidamised, kuid nii toimides olen pidanud kõrvale jätma või lühendama mõningaid näiteid. See kehtib ka arvukate jooniste kohta.

Meie folkloristidest koosnev uurimisrühm võttis oma kohustuseks kaasa aidata etnomeditsiinialase õpetuse levimisele sellega, et anda sellest võimalikult laiahaardeline ülevaade. Et vältida liiga subjektiivseid mõisteid, on kasutatud terminit botare ehk ravitseja. Ravitseja tähendab inimest, keda etnomeditsiinilisest aspektist võib käsitleda praktiseeriva arstina.

Põhimõtteliselt võib isegi litsentseeritud arst olla oluline uurimisobjekt, kuid et me antud juhul ei taotlenud institutsionaalsete ja ametlike sotsiaalsete suhete uurimist, mis kuulub sotsiaaltervishoiu valdkonda, on arst siinses kontekstis teatud ravitseja, kes on etnomeditsiinilisest seisukohast vähemoluline. Meie keskne uurimisteema on seega ametlike volitusteta meditsiinivaldkond, mida on iseloomustatud ka kui ebaseaduslikku meditsiinialast praksist (Rørbye 1976b).

\section{Arst ja arsti roll}

Skandinaaviamaades on olnud võimalik omandada meditsiinialast teaduskraadi enam kui 500 aastat (Gotfredsen 1973: 179 jj). Vaatamata sellele on sama aja jooksul meditsiinialast abi andnud ka teised enam või vähem spetsialiseerunud rühmad. Kuni 19. sajandi keskpaigani tegelesid kirurgiliste lõikuste ja verejooksudega akadeemilise hariduseta abiandjad, kes olid omandanud vastavad oskused. 
Viimase sajandi jooksul on teadusliku käsitluse haare avardunud. Tänapäeval leidub professionaalseid ravijaid, kellel on veterinaari, füsioterapeudi, kutsehaiguste spetsialisti, hambaarsti või muu ala teaduskraad. Järelikult pole võimalik rääkida kindlapiirilisest ravitsejaskonnast, sest see on olnud pidevas muutumises vastavalt sellele, kuidas on muutunud seadused. Iga kord, kui antakse luba uuele legitiimsele rühmale, määrab valitsus eksami, mille vastaval alal töötada sooviv isik peab sooritama. Seetõttu on arstide võimalused saada legitiimsete meditsiiniteenuste osutamise luba võrreldes ravitsejatega märkimisväärselt lihtsustunud.

Arstide töötingimused on muutunud. Vanasti oli arstidel oma patsientide kohta märkimisväärselt palju teadmisi. See kehtis mitte ainult kõrgklassi perekonnaarstide, vaid ka kogu maa provintsitohtrite kohta, samuti nende kohta, kes töötasid linnaäärsetes vaesteagulites. Arst oli teadlik oma patsientide ühiskondlikest võimalustest ja elukäikudest. Perekonnaarstid on olemas ka tänapäeval, kuid nende tegevus jääb märkamatuks võrreldes eriarstide, haiglate ja muude meditsiiniasutuste süstemaatilise ravipraktikaga. Haiguste ravimine on muutunud institutsionaalseks, fragmentaarseks ja intensiivistunud.

Arstide töö muutub mõistuspärasemaks ja tsentraliseeritumaks. Üha rohkem luuakse ravikeskusi, milles tegutseb hulk arste, kes tegelevad kindlaksmääratud arvu tunde suure hulga patsientidega.

Paljud praktiseerivad arstid peavad seda suundumust ülimalt negatiivseks ja süüdistavad selles sageli haiglaarste või haridussüsteemi. Nagu Taani arst Nils Nørrelund, kes kirjutab artiklis "En praktiserende læges betragtninger" ("Praktiseeriva arsti mõtisklused") järgmist:

Hoolimata sellest, millise eriala keegi ühel ilusal päeval valib, peaks sellel inimesel olema praktiseeriva arsti kogemus kuuest kuust ühe aastani. See annaks spetsialistile ettekujutuse sellest mitmepalgelisest inimhulgast, kelle seast me valime hoolikalt just need patsiendid, keda tema vastu võtab. See aitaks luua perspektiivi, millest spetsialistid on nende turvalises elus on täiesti ilma jäetud (Nørrelund 1977: 111-112).

Ometi pole see probleem nii lihtne. Vaevalt et muudetud koolitusprogramm probleemid lahendab. Arstid, nagu kõik muudki ametirühmad, alluvad seadustele, mille üle neil pole mingit mõju. Kuigi arstide tegevusel hoiab silma peal üks tugevaimaid kutseühinguid, on töömudelid Skandinaaviamaades muutunud (Jansson 1977: 53-54). Üldine suundumus on liikunud holistiliselt orienteeritud tegevuselt, milles indiviid oli keskne kõikides faasides, süsteemsemale, spetsialiseeritumale ja automatiseeritumale. Selline majanduslik mudel peab paika ka paljude arstide töö puhul. Tänapäeval on arstid spetsialiseerunud ravitavate organite (nt südame- ja kõrvaarstid), haige vanuse (pediaatrid 
ja geriaatrid), haiguspõhjuste (epidemioloogid) ja valdkondadevaheliste teenuste (radioloogid) järgi (Zachau-Christiansen 1977: 142-143). Kirurg, kes spetsialiseerub silmalõikustele, võib saada palju põhjalikumad eelteadmised nii inimorganismist kui ka kaasaegsetest tehnilistest võimalustest võrreldes arstidega, kelle tegevushaare on laiem. Investeeringud väljaõppesse ja perspektiivsesse aparatuuri toodavad kõrgemaid dividende, kui sellest kirurgist saab ekspert, kes suudab tipptasemel töötada kogu oma elu. Paljudele arstidele tähendab selline spetsialiseerumine protsessi killustumist. Eraldi spetsialiste õpetatakse välja protseduuri igaks etapiks, samal ajal muutub aga iga arst järjest eraldatumaks. Eesmärgiks on sarnaselt tööstusele teatav efektiivsus, mida iseloomustab kasvav toodangumaht ja ressursside intensiivsem kasutamine. Kõikides Skandinaaviamaades on suundumus väikeste kohalike haiglate sulgemisele, samal ajal kui tehakse enneolematuid investeeringuid hiigelhaiglate rajamiseks (Noltenius 1976).

Meedikud on alati tulnud kitsast sotsiaalsest rühmast. Nagu teistel akadeemilistel aladel, nii on ka arstiteaduse üliõpilased pärit peamiselt kõrgematest sotsiaalsetest kihtidest (Larsen \& Nielsen 1973). Isegi pärast seda, kui arstiteadust pääsesid õppima naised, moodustasid mehed suurema osa diplomeeritud arstidest (Larsen \& Nielsen 1973), eriti varasematel aegadel, mil arstid olid seotud linliku elulaadiga, samal ajal kui suurem osa rahvastikust kasvas ja elas maal.

19. ja 20. sajandi jooksul on arstiteadus olnud suunatud tehniliste oskuste täiustamisele holistilise vaatepunkti arvelt ning diplomeeritud arstid on saavutanud autoriteedi, mis on neile juurde andnud tubli annuse suveräänset võimu. Arstid ei tegele üksnes ravi määramisega. Üha enam konsulteeritakse nendega küsimustes, millel võivad olla nii ühiskondlikud kui ka majanduslikud tagajärjed. Tänapäeval oodatakse arstilt, et ta avaldaks arvamust teemade kohta, mis on seotud tööalase sobivuse, elukindlustuse, invaliidsuspensionide, küttetoetuste, lapsendamise ja muu sarnasega. Nagu üks arst seda väljendab: Arstist on, tahtlikult või mitte, saanud ravija asemel vahekohtunik (Voss 1977: 88).

Arsti oskus suhelda patsientide ja teistega, kes teda vajavad, sõltub suuresti tema isiklikest võimetest, sest ta ei ole selleks saanud mingit pedagoogilist ettevalmistust. Põhimõtted, nagu otsuste tegemises osalemine, demokraatia jms, purustavad autoritaarseid mudeleid ning levivad haiglates ja arstide ooteruumides kogu Skandinaavias.

Arsti roll on sajandite jooksul muutunud. Üks muudatus on lisandunud teisele ja sellisel kujul nagu tänapäeval peab arsti rolli ebameeldivaks suur osa, kui mitte enamik arste. 
Arstiga seotud stereotüüpide hulka kuuluvad valged kitlid, arstiriistad, kartoteegid ja patsiendikaardid kui meedikute staatuse ja ühtekuuluvuse nähtavad märgid. Sellele tuleb lisada arstikoolituse kaudu omandatud sotsiaalne staatus, mis eristab neid suuremast osast elanikkonnast ning lisaks riigi ja arstide ühenduste range kinnipidamine seadustest. Näiteks võiks tuua konfidentsiaalsusenõude, mis loob soodsa pinnase eksitavate müütide tekkimiseks ja nõudmise mitte avaldada arstide suhtes usaldamatust väljaspool nende erialaseid väljaandeid. See kõik võib osutuda tõsiseks takistuseks tavainimestele mõeldud koolitusprogrammide läbiviimisel (Lægeforeningens vejviser 1976: 82-83).

Paljud jõud võitlevad arsti stereotüüpse rolli vastu. See on roll, millel on ajalooline taust ja mida on ulatuslikult kasutatud ka kirjanduses. See on nagu fantoom, mis kaldub müstikasse ja võõrandumisse ning välistab igasuguse dialoogi või koostöö. Vähesed arstid - kui üldse mõni - toetavad seda fantoomi, kuid nad on siiski sunnitud säilitama oma rolli eelkõige patsientide ootuste ja neid ümbritseva keskkonna tõttu. Need ootused on välja kasvanud põlvest põlve kandunud pärimuslikest kujutelmadest arstide kohta.

Nende stereotüüpsete ootuste seas on usk arsti kui eksperti - inimesse, kes eeldatavasti on piisavalt tark, et ravida kõiki haigusi. Sellist ootust, nagu ka paljusid teisi levinud uskumusi arstide kohta, on raske mõjutada, sest need on osa kultuurist. Seda kuuleme kesksetest allikatest - endiste arstide ja arvamusliidrite suu läbi ning selle traditsiooni muutmiseks on vaja aega.

Arsti rolli ei saa defineerida selliselt, et arst otsustab ise, kuidas käituda. Võib ütelda, et omavahel on seotud kaks täiesti vastukäivat arusaama: ettekujutus arstist kui autoriteetsest teadlasest ning ka kui sotsiaalsest nõustajast. Teisalt on ühiskonna ja patsientide huvides pidada teda eksperdiks, sest see võtab neilt vastutuse ja annab usu sellesse, et nende probleem laheneb neist endist sõltumata. Seega on arst kingsepa, mehaaniku, inseneri ja teadmamehe (medicine man) rollis, kus keskseteks mõisteteks on ravi ja tervistamine. See roll võib olla ka arstile endale meelepärane, sest selle kaudu omandab ta maine ja võimu. Negatiivselt väljendades saab arstist võimu ärakasutaja ja üliinimene. Teises rollis on arst osast vastutusest ilma jäetud. Ta annab nõu ja tõstab patsientide ja/või ühiskonna teadlikkust sel määral, et nad ise oleksid võimelised haigusi ennetama või nendega võitlema. Selline arst on preestri või sotsiaaltöötaja rollis - märksõnadeks on siin profülaktilised toimingud ja teave, mis on seotud tervishoiualase haridusega. Ka see roll võib arstile meeldida, sest see võimaldab talle lisaks patsientidele suuremat kontakti ka teiste inimestega. Ühiskonna seisukohalt võib seda rolli pidada positiivsemaks pikemas perspektiivis, sest see panustab üleüldisse tervise paranemisse koos kõikide sellest johtuvate majanduslike tagajärgedega. Kuid poliitiliselt võib eesõiguse andmine ennetavatele programmidele olla keerukas. Kui need õnnes- 
tuvad, väheneb ravi vajavate haiguste hulk, kuid vastus küsimusele, millega seda selgitada, on sageli vaid hüpoteetiline. Teisalt on ühiskond olnud viimastel aastatel sunnitud tervishoiu küsimustes seisukohti muutma, sest kulutused sellele on märkimisväärselt kasvanud. Seetõttu on ennetavad programmid muutunud ühiskonnale hädavajalikuks abinõuks, nõnda et mitmes meditsiinivaldkonnas kardetakse ravimeetodite kvaliteedi aegumist või allakäiku (vt Betækning 809: 1977).

Patsiendile tähendab arsti ühiskondlik-meditsiiniline roll kasvavat respekti ja kontakti. Nagu taani arst Nils Nørrelund optimistlikult kirjutab:

Meie patsiendid muutuvad. Nad on järjest teadlikumad, saavutavad suurema enesekindluse ja loobuvad tasapisi arusaamast, et kõiketeadev arst ravib nad tõhusa raviga terveks. Tulevikus on meie ühised pü̈̈llused pigem võrdsete osapoolte pü̈̈dlused. Ainult teineteise teadmisi täiendades oleme võimelised saavutama häid tulemusi (Nørrelund 1977: 123).

Negatiivsetes terminites väljendatult saab arstist elukvaliteedile ja sotsiaalsele elukorraldusele spetsialiseerunud misjonär, või nagu on öelnud rootsi intellektuaal-ajaloolane Sven-Eric Liedman:

[---] tuim ametnik, kes annab välja käitumisreegleid kogu elanikkonnalevastavalt soole, vanusele ja sotsiaalsele klassile (Liedman 1975).

\section{Ravitseja ja ravitseja roll}

Ravitsejate kohta kasutatakse tänapäeval palju erinevaid nimetusi. Mõnikord kannavad need positiivset, mõnikord negatiivset suhtumist. Enimkasutatud väljendid on tähestikulises järjekorras järgmised: imearst ehk usu abil ravitseja (faith healer), loodusravija (nature-healer), rahvaarst (health practitioner), šarlatan (quack) ja tervendaja (healer); samas kui spetsiifilisemad terminid, nagu homöopaat, magnetiseerija ja refleksoloog viitavad ravitseja eelistatud meetoditele.

Ravitseja tegevus on illegaalne seni, kuni ta pole sooritanud spetsiaalset eksamit, mis annab talle õiguse oma ravimisviisi praktiseerida. Iga seadusevastane katse ravida teisi inimesi on õiguskeeles määratletud kui šarlatanlus. Kui tänapäeva ravitsejaid süüdistatakse peaaegu alati arstiabi andmisega seotud seaduste rikkumises, siis varasemal ajal mõisteti ravitsejaid süüdi erinevates kuritegudes. Võib leida kohtuprotokolle juhtumite kohta, mis on seotud šarlatanluse, nõiduse, pettuse, ravimiseaduste või erinevate ametialase tege- 
vuse seaduste rikkumisega ning abordi ja tahtlike nurisünnituste põhjustamisega.

Aastatel 1840-1935 mõisteti taani ravitsejad, kes määrasid ebaharilikke protseduure, süüdi pettuses, ent kui nad jäid oma arvamuse juurde, et nad ise usuvad oma ravi tõhususse, mõisteti nad õigeks (Rørbye 1976a: 39). Peaaegu sada aastat tegutses nimetamisväärne hulk praktiseerivaid arste, kes seaduse silmis olid šarlatanid või paremal juhul lihtsalt ebausklikud. Folkloristidele on huvi pakkunud just ravitsejad, keda kohtuprotsessides mainitakse harva. Imearstide uurimise kaudu on teadlased püüdnud tundma õppida rahvaomaseid uskumusi ja kogemusi (nt Hansen 1960-1961; vt Rørbye 1976b: 206 jj).

Ravitsejate tegevuse hindamisel tuleb neid võrrelda volitatud arstiabi andjatega. Mõned ravitsejad suhtuvad nendesse väga negatiivselt ja jäigalt ning määratlevad oma rolli sageli sihilikult arsti rolli alternatiivina. Paljud ravitsejad esindavad perekonnaarsti tüüpi ning leiavad aega teabe hankimiseks patsientide ja nende olukorra kohta, kui neil seda juba varem käepärast ei ole. See soodustab kontakti loomist ja teineteisemõistmist ning patsiendid ja nende lähedased kogevad seda sageli positiivsena, sest nad on harjunud eelkõige ametliku arstiabi andjate käitumismudelitega. Seda tüüpi ravitseja oli Skandinaaviamaades vanasti tavaline. Väikestes eelindustriaalsetes kohalikes kogukondades tundsid inimesed üksteist läbi ja lõhki. Nad olid ellujäämiseks sunnitud koos töötama ja üksteist usaldama ning kokkuleppeid sõlmima. Riigi vastutus nõrgemate kodanike ees on hilisema aja nähtus. See kerkis esile 19. sajandi jooksul koos liberaalsete ja sotsialistlike ideedega ning leidis poliitilise kajastuse põhiseaduses ja sellest lähtuvates sotsiaalaktides. Enne seda oli indiviidi turvalisuse tagamisel väga oluline kohalik kogukond. Sealsed ravitsejad olid selle keskkonna lahutamatu osa (Rørbye 1976b: 209 jj). Ravitsejaid leidub tänapäeval ja ilmselt edaspidigi sel lihtsal põhjusel, et nad kujutavad endast alternatiivi arstidele. Nende tegevuse järele on alati nõudlust.

Universaalset tüüpi ravitsejad, kes kasutasid aeganõudvaid ravimeetodeid, polnud vanasti aga ainukesed. Teenimise peal väljas olevad ravitsejad rändasid laadalt laadale või asusid elama linna, kus nad pakkusid oma ravioskusi. Nagu arstid, kes tegutsevad ekspertide ja spetsialistidena, kuid tunnevad end alahinnatud teadlastena, olid need ravitsejad ümbritsenud ennast sageli väljakutsuvalt ülepingutatud meditsiinilise masinavärgiga - uhkete vastuvõturuumide, paljude tehniliste instrumentide, valgetesse tärgeldatud kitlitesse riietatud abiliste ja muu sarnasega. Sellise välise atribuutika abil on mõned ravitsejad püüdnud tekitada oma patsientides usaldust, mis põhineb traditsioonilisel kujutlusel arstist kui eksperdist. Et ravitsejad on suuresti individualistid, ei saa neid rollitüüpe pidada tavapärasteks, vaid pigem äärmuslikeks. Need äärmused esindavad kõiki alates ravitsejast, kes sobib välispidiselt arsti rolli 
paremini kui tõeline arst, kuni ravitsejani, kes püüab sellest rollist võimalikult erineda. Mõlemad äärmused eksisteerisid nii vanasti kui ka hilisemal ajal.

Võib-olla jõuame tõele lähemale, öeldes, et ravitsejad moodustavad suurte erisustega rühma, mida iseloomustab meetodite paljusus, erinev inimesetaju ja ühiskondlik orientatsioon. Tänaseni pole tekkinud küsimust kontrakultuurist (siiski, vt Rørbye 1976a: 241-242; Rørbye 1978a: 37-141).

\section{Haigus, tervis ja ravimine}

Mõisted tervis ja haigus ehk tõbi on meie igapäevasesse keelekasutusse niivõrd juurdunud, et kiputakse unustama, kui kaugel on need objektiivsusest. Räägitakse üksikutest haigustest - leetritest, tuberkuloosist, diabeedist jne ning öeldakse, et ollakse oldud haige ja nüüd ollakse taas terve. Ja me võime lugeda piirkondadest, kus on liikvel rohkelt iseäranis raskeid haigusi.

Tegelikult kasutame me neid mõisteid erinevalt, kuid see tekitab harva probleeme, need on muutunud üldlevinuks. Paljud patsiendid on kogenud olukorda, kus arst või mõni teine seaduslik arstiabi andja ei aktsepteeri kõiki vaevusi haigusena ja saadab nende käes vaevleva inimese koju, kirjutades talle võib-olla unerohtu, eelkõige aga soovitades asja rahulikult võtta. Osa neist patsientidest tunneb suurt vajadust leida oma haiguse leevendamiseks mõni alternatiiv. Nad mitte ainult ei tunne ennast halvasti, vaid rahuldamata jääb ka nende vajadus hoolitsuse ja abi järele.

Viimastel aastatel on rahvaomaste haiguskäsitluste uurimine saanud meditsiiniantropoloogidele tähtsaks ülesandeks. Selle põhjuseks on asjaolu, et arengumaade elanike ja läänemaades koolitatud arstide vahel on tekkinud tõsised ja teravad probleemid. Lääne arstiteaduses läbi viidud uuringute põhjal on lõpuks jõutud arusaamisele, et haiguste bioloogilisel käsitlemisel võivad olla piirid ning see võib olla vaid üks paljudest käsitlustest. Haiguse mõiste on määratletud ühiskondlikult ja kultuuriliselt ning selle asemel, et vaadelda haigust kui eraldiseisvat loomulikku ilmingut, võib seda käsitleda kui organismiga seotud seisundit. Seega ei saa haigust ja tervist iseloomustada lihtsalt kui objektiivseid mõisteid. Ka Skandinaaviamaades võib kohata nendesse mõistetesse erinevat suhtumist. Tuleb kindlasti rõhutada, et Maailma Terviseorganisatsiooni (World Health Organisation = WHO) haiguse definitsioon lähtub suuresti patsiendist endast ja tema määratlusest:

Tervis on täieliku kehalise, vaimse ja sotsiaalse heaolu seisund, mitte aga haiguse või jõuetuse puudumine (WHO 1946). 
Tuleb täheldada, et koos mõistega haigus opereerib WHO ka mõistega jõuetus. Teiste sõnadega - WHO kasutab oma ametliku seisukoha väljendamiseks nelja terminit: kahte positiivset - tervis ja heaolu - ning kahte negatiivset, millest haigus sisaldab sündmuste käiku ja lõpetatust, samas kui jõuetus on midagi kauakestvamat ja püsivamat. Definitsiooni lõpuosa on põhjustanud ka mõningast kriitikat. Osa inimesi peab mõningaid pingeid inimese olukorra ning teatud kõrgemate eesmärkide ja ideaalide vahel positiivseks ja väärtuslikuks, teised rõhutavad, et heaolu võib saavutada ka näiteks ravimite ja stimulaatorite manustamise teel või apaatiaseisundis ning see võib olla igati kahetsusväärne nähtus, mis on murettekitavalt sarnane Aldous Huxley raamatus Hea uus ilm (Brave New World) kirjeldatule.

Kui rahvaomaste haiguskujutelmade uurimine on oluline ülesanne arengumaades, siis vaevalt on see nii ka industriaalühiskonnas, kus inimeste käitumine osutab selgelt ametliku arstiabi piiratud kasutamisele. Ameerikas tehtud uurimuse põhjal kogeb kolm neljandikku tuhandest küsitletud täiskasvanust ühel või enamal korral kuus haigusilminguid, kuid vaid neljandik neist konsulteerib sama perioodi jooksul arstiga ühe või rohkem kordi. Selle uurimuse kohaselt pöördub arsti poole vaid iga kolmas haigestunu (White \& Williams \& Greenberg 1961). Enamik jätab arstiga üleüldse konsulteerimata. See on tavaline paljude haiguste puhul: migreenist põhjustatud peavalud, seljavalud, seedehäired, kurgu- ja hingamisteede haigused. Teised patsiendid võivad seevastu olla saanud arstiabi, aga pole sellega rahul. Osa neist pöördub abi saamiseks alternatiivmeditsiini poole (Observa 1971). Seda võib väljendada järgnevalt: neist Skandinaaviamaade elanikest, kes tunnevad ennast mingil ajal haigena, saab kõigi andmete põhjal otsustades teadusliku taustaga arstiabi vaid väike hulk inimesi. See võib väga kergesti põhjustada või soodustada potentsiaalsete patsientide usalduse kadumist arstiteadusse mis võib aja jooksul süveneda. Osa inimesi pöördub arsti poole ainult siis, kui usuvad, et tegemist on bioloogiliselt kergesti diagnoositava haigusega. Nad vaikivad maha kõik muud vaevused, kerged haigused ja väikesed valud või üritavad neid ravida koduste vahenditega ja paremate või halvemate soovituste järgi, mis pärinevad sõpradelt, reklaamidest või ravitsejatelt. Seega on rahvalikul arusaamal arstide haiguskäsitlusest ebameeldiv kõrvalmõju, mis võib viia tõelise lõhe tekkimiseni. Mõned arstid aitavad ise sellele suundumusele kaasa, olles kiired saatma patsiente abi andmata minema ja näidates üles ärritust, kui keegi on ilmunud vastuvõtule ilma konkreetsete sümptomiteta. Teiselt poolt võib arstide seas kuulda ka Odüsseia-sündroomist, mis tähendab, et potentsiaalne patsient saadetakse ühelt uuringult teisele ja talle tehakse mitmeid ravikuure, kuigi tegemist ei ole haige inimesega. Teaduslikult on "mitte-haige" olemist palju raskem diagnoosida kui "haige" olemist (Lærum 1976). 
Üheks kindlaimaks haigustunnuseks peetakse lääne kultuuris kõrgenenud kehatemperatuuri ja palaviku mõõtmine on haigestumisega seotud kahtluste puhul tüüpiline rituaalne toiming. Arstiteaduse seisukohalt on kõrgenenud kehatemperatuur märkimisväärne bioloogiline kõrvalekalle ja 20. sajandi jooksul on see rahva seas tugevalt kanda kinnitanud kui konkreetne haigussümptom. Kuid mida teha siis, kui palavikku ei ole, aga enesetunne on halb? Reageeringud on kõikvõimalikud - alates katsetest halba enesetunnet eirata ja jätkata normaalse koormusega tööd kuni kultuuriliselt aktsepteeritud haiguskäitumiseni, nagu voodis lamamine vms.

Teine rahva seas aktsepteeritud haigustunnus, mis võib põhjustada arstiteaduses palju probleeme, on valu, mida võidakse kirjeldada mitmel viisil, kuid mitte kunagi ammendavalt. Miski, mis põhjustab ühele inimesele palju ebameeldivusi, on teisele tajutav vaid ebamäärasena. Meil puudub "valu mõõdupuu", mis võimaldaks üksteise aistinguid võrrelda. Isegi ühe isiku puhul ei saa määratleda, kas võimalik bioloogiline hälve, mis avaldub valuna, vajab ravimist või mitte. Et valu pole sümptomina käega katsutav, ebaõnnestuvad üksteise järel arstide püüdlused vabastada patsiente valust. Seetôttu on valu üks neist suhtelistest aistingutest, mis võib ajendada pöördumist ravitseja poole.

Võib nimetada ka paljusid teisi sümptomeid, nagu sügelus, vilin kõrvus, lihaskrambid, minestushood, värinad ja äge valu. Osasid neist peetakse haiguse tunnusteks, teisi mitte. Ühes ameerika uurimuses toodi välja selge erinevus kõrgemate ja madalamate sotsiaalsete rühmade vahel, s.o rühmade vahel, kellel on erinevad rahalised võimalused (Koos 1954). Sageli sõltub sümptomite tõlgendamine ka nende rohkusest, eriti aga inimese kogemustest ja tema lähikonnast. 1969. aastal Taanimaal Roskildes läbi viidud küsitluses püüti koguda kindlat ja konkreetset informatsiooni nende sümptomite kohta, mis sundisid inimesi arsti poole pöörduma. Enamik vastajaid ei suutnud sellele küsimusele vastata või vastasid, et ei tea. Kommentaarides mainisid mitmed vastanutest, et küsimus oli ebaselge ja arsti poole pöördumine sõltus valu intensiivsusest ja kestvusest. Sellest järeldasid autorid, et välitöödel läbi viidav küsitlus oleks ilmselt olnud tõhusam, kui nad oleksid pööranud suuremat tähelepanu ühiskondlik-kultuurilisele aspektile (Holst \& Scocozza 1972).

Ametlik lääne haiguskontseptsioon on Ameerika Ühendriikide teadlase Horacio Fabrega juuniori määratluse kohaselt bioloogiline, milles termin haigus väljendab arstiteadusliku definitsiooni järgi häireid organismi funktsioonides ja/või mistahes elundites ja kehaosades. H. Fabrega lisab:

Pole mingit põhjust kahelda, et inimesed on põhiolemuselt igal pool ühesugused, ja see lubab arstidel anda hinnanguid haigestumisele ja haigustele (Fabrega 1972). 
See tähendab esmalt, et haigust on määratletud kui midagi objektiivset, ning teiseks, et selline teaduslik lähenemine muudab inimestele universaalselt omased haigused prioriteetseteks üksikute haiguskulgude ees. Inimkeha on jagatud patoloogiliste seisundite alusel väiksemateks osadeks ning need omakorda erinevateks haigusteks või tõbedeks ja patoloogilisteks sümptomiteks, sarnaselt taksonoomiale botaanikas.

Võrreldes ametlikult tunnustatud haiguse definitsiooniga on olemas terve hulk erinevaid rahvapäraseid seletusi. Rahvapärased definitsioonid on märksa subjektiivsemad ning H. Fabrega jagab need olemuselt biheivioristlikeks ja fenomenoloogilisteks. Biheivioristlikust seisukohast sisaldab haigus teatud muutusi käitumises, mida kultuurisiseselt peetakse haigustunnusteks (Fabrega 1972). Kui Taanis tullakse tööle, pikk sall ümber kaela mähitud, tõlgendatakse seda külmetuse või gripitaolise viirushaiguse märgina. Meie perekonnas peetakse haiguse märgiks seda, kui keegi meist heidab ootamatult pikali ja hakkab soiguma. Haiguskäitumine on sotsiaalselt ja kultuuriliselt määratletud ja on suur hulk käitumisviise, millega lähikondlastele oma haigusest mär$\mathrm{ku}$ anda.

Fenomenoloogiline haiguse definitsioon on seotud aistingutega, mis ei seondu inimese tavapärase olekuga. H. Fabrega järgi, kes siinkohal põhjendab oma seisukohti isiklike meditsiiniantropoloogiliste kogemustega, viivad inimesi tasakaalust välja välised tegurid, isikud või erakordsed jõud (Fabrega 1972). On mitmed tunnused, mis on omased kõigile kolmele haiguse definitsioonile igal haigusel on algus, kestus ja lõpp. Räägitakse haige olemisest ja terveks saamisest; peale selle seostatakse haigust selgelt määratletud organismi, antud juhul inimese omaga. Lisaks ajalistele ja ruumilistele dimensioonidele näitavad haiguse definitsioonid, et haigus on soovimatu ja negatiivne seisund, mis destabiliseerib inimest tervikuna ja põhjustab talle kannatusi. Vastupidiselt neile kolmele käsitlusele leidub inimesi, kelle arvamuse kohaselt on haigus midagi normaalset. Inimene on alati suuremal või vähemal määral haige ja suuremal või vähemal määral terve. Organism püüab saavutada tasakaalu, kuigi ei ole selleks võimeline. Tegeliku elukäiguga kaasneb dünaamilisi "võite" ja "kaotusi". Iga kaotus põhjustab pingeid ja stressi, mis on organismile kahjulikud, samas kui võidud annavad uut energiat. H. Fabrega pole kõnealusele haiguskäsitlusele nime andnud. Ta usub, et selline haiguskäsitlus on kasutusel vaid teadusringkondades, kus tegeldakse loodusliku tasakaalu uurimisega. Seega võib seda nimetada ökoloogiliseks haiguskontseptsiooniks.

H. Fabrega haiguskontseptsioonide mudelid põhinevad tema meditsiiniantropoloogilisel uurimistööl, kus erinevate kultuuride suhtumine normaalsusse ja ebanormaalsusse loob eeldused tõsiste probleemide ja konfliktide tekkeks. Kui põhjapanevad on aga need antropoloogilised vaatlused etnomeditsiini uuri- 
mise seisukohalt? Ehk teisisõnu: kas Skandinaavia kultuuriruumis on üheaegselt olnud käibel erinevaid haiguse definitsioone, mis on tekitanud probleeme? Kui nii, kas siis on H. Fabrega liigitus piisav?

Tänaseni pole olemas põhjalikku käsitlust haiguse mõiste ulatusest ja ajaloost, kuid suur hulk kohtuprotsesse ja rahvapäraseid seletusi annavad tunnistust, et usk üleloomulikesse olenditesse ja jõududesse kestis veel kaua aega pärast ametlikku lahtiütlemist nõiausust (nt Henningsen 1975, Rørbye 1976a, Tillhagen 1958).

Fenomenoloogiline haiguskontseptsioon oli seotud maagiliste haigusseletustega. Kannatusi käsitleti kui omaette eksisteerivat kurjust, mis tuli hävitada. Ravitseja võitles selle jõu vastu ja kui ta osutus tugevamaks, vabanes patsient kannatustest, sõltumata sellest, millisel moel need olid avaldunud (Leach 1976: 30). Mitte alati ei nimetatud patsienti haigeks, ta võis olla näiteks nõiutud, haldjatest ära tehtud, kurjast vaimust vaevatud vms (Clements 1932; Honko 1959; Matthiessen 1967; Tillhagen 1958). Eksortsismi, st kurjade vaimude väljaajamisega tegeldakse isegi tänapäeval, mis näitab, kuivõrd tugevalt ja agressiivselt võivad avalduda emotsioonid, kui midagi tajutakse loomuvastasena (Alver 1978). Paljud maagilisi tõrjevõtteid kasutavatest ravitsejatest rakendasid samu ravivõtteid, ravides haigusi, mida arstiteaduses peetakse üksteisest üsna erinevateks, kuid mida uskujad seostasid ühe ja sama jõuga (Biering 1973: 27). See põhjustas palju kriitikat ja isegi naeruvääristamist nende poolt, kes võitlesid nõiduse vastu. Ka tänapäeval kasutatakse sama argumenti, kuigi nüüd on peksupoisteks saanud tavalised arstid. Dr Peer Jansson ironiseerib järgnevalt:

Nõrku närve võib tegelikult parandada rahustitega, vaatamata sellele, kas tegemist on tööalaste või koduste nääklustega (Jansson 1977: 50).

Juhul kui arst ei ole võimeline täheldama patsiendil mingeid bioloogilisi kõrvalekaldeid, tekib konflikt. Kui patsient läheneb oma haigusele biheivioristlikust või fenomenoloogilisest seisukohast, tahab ta eelkõige vabaneda halvast enesetundest. Ta tahab jälle terveks saada. Õpetatud arst omakorda rakendab analüütilist meetodit, kuigi tal on üksnes ähmane ettekujutus sellest, millise ravi peaks ta määrama, kui tal puuduvad igasugused kultuurilised ja pärimuslikud taustateadmised. Arsti ja patsiendi huvide kokkupõrge võib viia selleni, et kumbki jääb oma seisukohale, mis tähendab veel kord, et arstide teadmistepagasist saab peaaegu monopol, nagu Skandinaaviamaades, kus on sajandite jooksul on loodud domineeriv teadusel põhinev tervishoiusüsteem. See süsteem on niivõrd sügavalt juurdunud, et vaevalt tekib seal küsimust ravitsejate mõjust tavameditsiinile, v.a juhul, kui neid kasutab litsentseeritud arstiabi andja. Tavaliselt tõrjutakse need mõjutused tagasi kui ebateaduslikud. Suur 
hulk patsientidest on niisuguse suhtumisega tuttavad. Kasuliku dialoogi asemel tervishoiusüsteemiga otsivad nad alternatiivseid võimalusi. Seega on võimalik tõestada, et igal ajal on erinevatesse haigustesse suhtumine olnud erinev nii arstide kui ka rahva hulgas ning olukorra muutudes isegi ühe ja sama isiku puhul. Edasised uurimused peaksid neid tähelepanekuid täpsustama ja süstematiseerima. Juhuslikult valitud näited varasemast ja hilisemast materjalist osutavad, et vastupidiselt H. Fabrega kirjeldusele ei eksisteeri mingit piiratud hulka ökoloogiliste huvidega teadlasi, kes määratlevad haigust ja eriti tervist kui abstraktseid äärmusi, mis ei saa eksisteerida teineteisest sõltumatult. - Tänu taevale, ma olen nii terve ja reibas, et igaüks võib kadestada, ütles mulle kord üks vana mees. Loomulikult ma ei näe ega kuule enam nii hästi ja puusas on mõnikord valu. Pärast sellist väidet, mis on tegelikult väga vastuoluline, aga enam-vähem tüüpiline, on täiesti absurdne küsida sellelt mehelt, kas ta on tegelikult haige või terve. Olen esitanud sama küsimuse ka teistelt samalaadsetes olukordades inimestelt, et probleemile valgust heita. Tüüpiliseks vastuseks on, et nad pole haiged, kuid hiljuti on neil olnud mingi viirushaigus, põiepõletik või mõni muu tõbi. Need inimesed lähtusid oma vastustes bioloogilisest haiguskontseptsioonist. Nagu paljud teisedki, ei pöördunud nad oma igapäevahädade leevendamiseks arsti poole seni, kuni tegemist polnud millegi ägedaloomulise, seletamatu või äärmiselt tülikaga.

H. Fabrega tutvustab bioloogilist definitsiooni kui ainsat lääne meditsiinis tunnustatud haiguskäsitlust. See on ilmselt ülemäärane lihtsustus, sest haiguse taksonoomia muutub mitte ainult kultuurist kultuuri, vaid ka aja jooksul.

19. sajandil väitlesid mitmed arstid innukalt selle üle, kas nad peaksid ravima inimesi või tõbesid. Inimesse tuli suhtuda kui identiteediga tervikusse, mida võis suuremal või vähemal määral muuta, mitte aga kui sõltumatute funktsioonidega autonoomsete osade kogumisse. Seega olid nad vastu määratlusele, mille kohaselt oli inimene kui masin, millel võis esineda rikkeid. Üks taani maa-arst kommenteeris 1860. aastal irooniliselt Kopenhaageni Frederiki haigla aruannet, milles väideti, et ravitud on 1295 patsienti ja 1454 haigust (Giersing 1861).

Teadupärast on süstemaatiline meditsiiniline lähenemine haigustele saavutanud ülekaalu, kuid ka 20. sajandil on arste, kes hoidavad kinni vanast holistilisest lähtekohast (Johansen 1912; vt Rørbye 1976a: 233-234). Eriti psühhiaatrias kohtab seda rahvapärastes arusaamades nii olulist mõtteviisi, mis on lähedalt seotud biheivioristliku, fenomenoloogilise ja ökoloogilise kontseptsiooniga. Sellele vaatamata suudavad psühhiaatrid harva ravida patsientide somaatilisi haigusi, isegi kui need on põhjustatud või mõjutatud füüsilisest haigusest. Inimorganismi määratlemist aparaadi või masinana, on hiljaaegu 
tuliselt kritiseerinud sotsiaaltervishoiule orienteeritud arstid. Viimased järgivad loomulikult bioloogilist haiguskontseptsiooni, kuid otsivad sümptomitele seletusi väliste ja sisemiste põhjuste seast, nagu pärilikkus, keskkond, varanduslik seis, elukutse jms.

Kokkuvõtvalt võib öelda, et haigust vaadeldakse osaliselt kui objekti ja osaliselt kui organismi kvaliteeti; haigus on ajaliselt ja ruumiliselt laialt levinud ja ühiskonnas soovimatu. Haiguskontseptsioonide tõlgendamine ja haiguskäitumise valik on sotsiaalselt ja kultuuriliselt mõjutatud isegi neil juhtudel, kui tegemist on bioloogiliste kõrvalekalletega. Peale selle võime kinnitada, et Skandinaaviamaades leidub mitmeid haiguskontseptsioone: bioloogiline (mille alla kuuluvad loodusteaduslikud ja sotsiaaltervishoiualased mõisted), biheivioristlik, fenomenoloogiline ja ökoloogiline. Uued uurimused peavad näitama, kuivõrd neid mõisteid erinevates rühmades aktsepteeritakse ja kas on olemas veel muid tüüpe. Bioloogiline kontseptsioon põhineb ametlikel seisukohtadel (ka poliitilises plaanis), samas pole see nii patsiendile orienteeritud kui mõned teised suunad, mis ilmutavad ennast eriti mitteametlike kanalite vahendusel. Samal ajal kui arstiteadusliku käsitluse järgi on inimene objekt - isik, kellega tuleb tegelda, on ta teiste käsitluste kohaselt palju suuremal määral subjekt, st isik, kes tegutseb ja tunneb. Seega mõistetakse viimasel juhul haigust sageli terviku osana, samal ajal kui bioloogilise definitsiooni kohaselt vaadeldakse haigust eraldiseisvana.

Etnomeditsiini seisukohast ei saa tekkida küsimustki ainult ühest haiguskäsitlusest. Selle asemel tuleb rääkida arvukatest haigustega seotud müütidest või haigeks olemise normidest, mida võib jagada suurematesse või väiksematesse rühmadesse ja mis on rahvapärimuse osa. Teiste sõnadega on etnomeditsiiniline haiguskäsitlus ajaloolisest, geograafilisest ja ühiskondlik-kultuurilisest vaatepunktist dünaamiline ja muutlik. See lähtub alati inimestest enestest, haigussituatsioonis olijatest, või täpsemalt väljendudes, sellest inimeste rühmast, keda on selles kirjutises teises kontekstis iseloomustatud etnomeditsiinilise mõiste abil kui potentsiaalseid patsiente. Etnomeditsiinilise haiguskäsitluse mõistmiseks tuleb seda suhet siiski eelnevalt põhjalikumalt selgitada.

\section{Patsient, potentsiaalne patsient ja patoloogiline draama}

Väga kitsas ametlik haiguskäsitlus, mis on peaaegu valdavalt valitsenud viimase paari sajandi jooksul, on panustanud sellesse, et haiget määratletaks kui raviobjekti. See kajastub ka tervishoiualastes töödes, mis seda dogmat 
kinnitavad. Patsientide ravist on seega järele jäänud ühekülgne bioloogiliste tekkepõhjustega haiguste ravi. Arsti peamiseks ülesandeks on olnud haiguse tekkepõhjuste kindlakstegemine, selle kulgemise ja sümptomite väljaselgitamine, edasise prognoosimine ja ravi kirjeldamine. Selliste haiguskirjelduste koostamine oli tavaarstide peamine eesmärk.

Tänapäeval muutub mõiste patsient üha problemaatilisemaks. Laiema definitsiooni kohaselt on patsient inimene, kes ei tunne end hästi, kes valib haiguskäitumise või kes sellesse rolli määratakse. Palju räägitakse patsientidest või haiguse rollist. Patsiendi mõistet seostatakse haiguskäsitusega samamoodi, nagu on sellega seotud normaalsusest kõrvalekaldumine.

Tegelikult on äärmiselt tähelepanuväärne, et patsienti on hakatud normide rikkumise pärast häbimärgistama (Goffman 1963), st tema puuete pärast määratakse talle ühel või teisel moel piiranguid. See on küll täielikus vastavuses haiguse määratlemisega millegi negatiivsena, millest tuleb üle saada, samas on see aga tugevas vastuolus reaalsusega. Haiguse või jõuetuse äärmuslikem tulemus on, et inimene kukub kokku ja sureb. See on paratamatu ja normaalne protsess, sest tervis on abstraktne mõiste, mis kujutab endast müüti või utoopilist nägemust ideaalseisundist (Honko 1972; Thyssen 1977). Kogu elanikkond - õpetlased, arstid ja suures osas ka lihtinimesed ise - usuvad sellesse müüti, mida toetab ulatuslik ja erakordselt ilmekas rahvajututraditsioon (vt alapeatükki Etnomeditsiinilised jutud igapäevaelust. Esimene põhitüüp: ravijutud). Rahvaomastes juttudes ravimisest on traditsiooniline sündmuste kulg alates haigestumisest kuni tervenemiseni dramatiseeritud. Inimeste kogemused muutuvad kulunud stereotüüpse tegevusmudeliga saagadeks, kus patsiendist saab sageli tegus kangelane, kes ei anna alla, samas kui arstile või ravitsejale on määratud abistaja roll. Massimeedia on eriliselt panustanud nende normide ja ideede kinnistamisse, kirjeldades kangelaslikke epohhiloovaid arstiteaduslikke avastusi või imepäraseid tervenemisi.

Seepärast tuleb endalt küsida, miks iseloomustatakse haigust kõigest hoolimata ikka veel anomaalia (Bang 1852) ja vastuoluna ning tervist millegi normaalsena. Igale ühiskonnale on omane vajadus jätkuvuse järele ja usk tulevikku, mis ulatub üksikisiku elust kaugemale. Kui haigus tabab nõrku, st eelkõige lapsi, eakaid ja puuetega inimesi, saab neist veelgi suurem koorem ühiskonna töötavatele liikmetele. Samavõrra ohtlik on olukord, kui haigus nõrgestab elanikkonna kõige aktiivsemad liikmed. Nende töövõime väheneb või hääbub ja selle kaudu satub ohtu kogu ühiskonna ellujäämiseks vajaminevate põhiväärtuste tootmine. Bioloogiliste ellujäämisvõimaluste seisukohalt oli selline oht Skandinaaviamaades mõned põlvkonnad tagasi täiesti reaalselt olemas. Ellujäämisvõimaluste alla võib aga lugeda ka sotsiaalkultuurilisi vajadusi, mis on muutunud inimese või inimrühma ellujäämiseks oluliseks (Wolf 
1973). Järelikult esindab haigus midagi ohtlikku ja destruktiivset. Seda võib väljendada järgnevalt: haigus peegeldab kaost, mis on ritualiseerimise tõttu muutunud sotsiaalselt aktsepteeritavaks. Haigusele reageerimine baseerub ajaloolisel teadmisel sündmuste kulgemisest ja haigus on jagatud faasideks. Seda ilmingut kinnitab uurimus, mis on keskendunud pika kuluga haigustele, nagu näiteks tuberkuloos (Roth 1963). Algfaasis jääb inimene haigeks, st oletatakse, et enne seda oli ta terve. Seejärel, kui sündmuste kulg intensiivistub, lähenedes kulminatsioonile, omandab vaatluse all olev inimene patsiendi rolli ehk jääb haigeks. Haige inimese puhul võib täheldada subnormaalset käitumist. Teiste sõnadega, tema käitumist võib pidada normaalseks teatud patsientide rühma sees, kuhu ta parasjagu kuulub, samas kui see erineb tavaliste ühiskonnaliikmete omast. Kui haigus on jõudnud lõppfaasi, siis draama lahendatakse ja inimene saab jälle terveks. See, mida kujutati kaosena, saab jälle korda. Toimub normaliseerumine ja tervisemüüt leiab ravi tõlgendamise kaudu kinnitust. Häbimärgistava käitumise tõttu ametivõimude, igapäevase keskkonna, aga ka patsiendi enda poolt surutakse hädaoht maha sel moel, et ta muudetakse osaks patoloogilises draamas.

Inimeste katsed mõjutada tervikut ja kindlustada korda, nagu ka teised samalaadsed ilmingud, lõpevad haiguse ajal nii, et need ümbritsetakse siirderiitusega (nt Honko 1976; Turner 1969), mille tähendus ja ravimisega seotud tagajärjed ootavad veel interdistsiplinaarset analüüsi. Paljud Skandinaaviamaade patsiendid peavad näiteks voodisse pikali heitmist ebanormaalseks, isegi kui see oleks antud juhul igati kasulik. Teised inimesed söövad teatud kindlaid toiduaineid - igaüks võib siia lisada arvukalt näiteid. Lühiajalise haigusega patsiendid, kes järgivad ideaalset patoloogilist draamat, saavad oma lähikond-

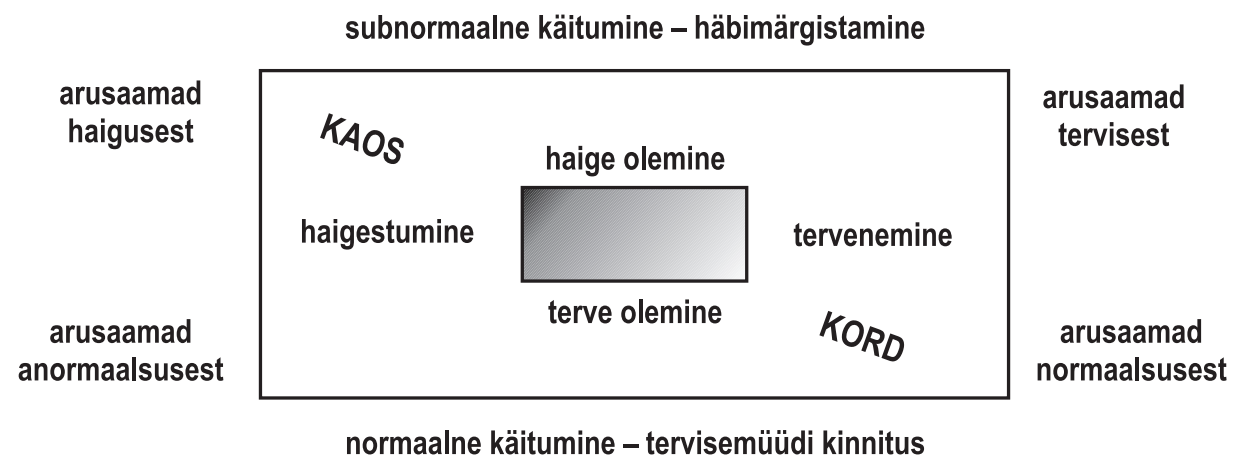

Joonis 1. Patoloogilise draama struktuuri mudel. 
lastelt palju heakskiitvaid hinnanguid. Mitmed uurimused on osutanud, et kui ravi ei anna oodatud tulemusi, algab vähehaaval negatiivsete sanktsioonide rakendamine (nt Calais 1963; Schneider 1947). Paljud just krooniliste haigustega inimesed on seda kogenud ja tekib küsimus, kas ümbritsevaid inimesi ei mõjuta mitte lühiajalised vaimsed häired, mille kulgu ja ravi harva teadvustatakse. Igatahes tuleb rõhutada, et olukorra kontrollimine on kultuuriliselt konstrueeritud. Külmetushaigust põdev inimene võib ennast veel kord külmetada, saada kroonilise hingamisteede haiguse jne, aga skandinaavlased on kasvatatud nägema neid haigusi kui järgnevaid haigusi ja niisugustena aktsepteeritakse neid kõigele vaatamata, isegi kui haigused on kauakestvad või korduvad (vt joonis 1).

Sellest võib järeldada, et igas ühiskonnas leidub patsiente, keda peetakse kas vastuvõetavateks või vastuvõetamatuteks, headeks või halbadeks. Selline hinnanguandmine, nagu patoloogiline draamagi, on mõjustatud sotsiaal-kultuuriliselt. Nõnda teeb ka see läbi protsessuaalsed muudatused ja on suuresti sõltuvuses ajaloolisest ja majanduslikust olukorrast.

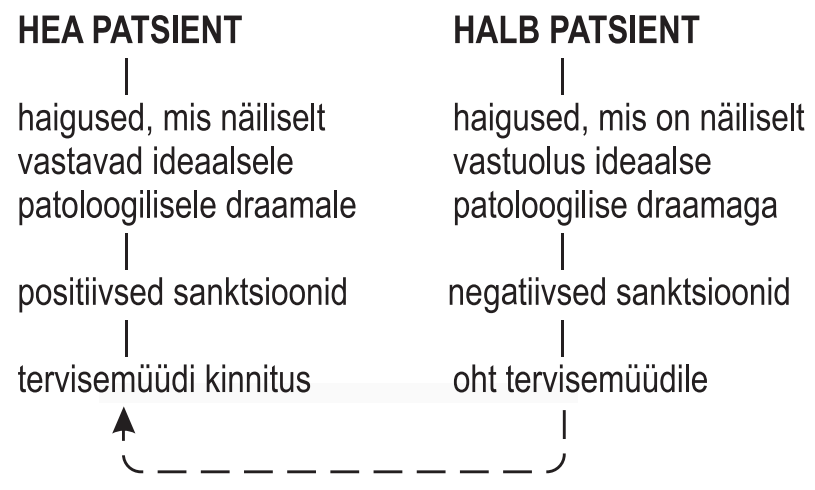

Joonis 2. Hea ja halva patsiendi üldised tunnused.

Halvad patsiendid on väga motiveeritud eksperimenteerima, sest nad ei kannata mitte üksnes haiguste tõttu, vaid nad on ka sotsiaalkultuurilise surve all. Kui litsentseeritud arstiteadus ei anna neile paranemiseks mingeid väljavaateid, otsivad nad alternatiivseid ravivõimalusi. Sel viisil võib halb patsient saavutada sageli isegi positiivse tulemuse, millel võib mõningal juhul olla pikemas perspektiivis ka bioloogiline tähendus. Haigus, mis on oma pika kestvuse tõttu piirangute alla seatud, jaotatakse taas faasideks. Halvad patsiendid, kes 
käivad ühe tohtri, ravimenetluse ja ravitseja juurest teise juurde, saavutavad kunstlike vahenditega kindla kontrolli oma probleemide üle. Oma püüdluste kaudu kinnitada tervisemüüti avaneb neil võimalusi jagada heade patsientidega mõningaid kultuuriliselt määratud hüvesid. Haige olemisele on väga lähedal inimesed, kes on kauakestva või korduva haiguse tõttu stressis. Nendele võib abiks olla probleemi jagamine faasideks - see hoiab neid lootusetusest kokku kukkumast.

Halvale patsiendile sarnased mõisted on halb arst ja halb ravitseja, st arst või ravitseja, kes pole olnud võimeline patsienti aitama. Teiselt poolt võib rääkida heast arstist või ravitsejast, kui patsient, järgides talle määratud ravi, terveneb.

Etnomeditsiini valdkonnas ei saa uurija rahulduda vaid patsiendi uurimisega, kuidas ka patsienti ei määratletaks. Tuleb alustada potentsiaalsete patsientidega. Selle arusaama kohaselt on kõikidel inimestel suhted patsiendiks olemisega ja kõik on osalised patoloogilises draamas. Muidugi on ainult mõned patsiendi rollis, aga ka kõik teised on seotud kindlasti suhetega, mis mõjutavad nende käitumist. Patsiendi perekonnaliikmed, kolleegid, naabrid ja teised haigele lähedased inimesed võivad ka oma käitumist muuta. Nad annavad kergemini andeks, räägivad õrna häälega, täidavad soove, võtavad endale uusi kohustusi, saadavad lilli ja kingitusi jne. Rootsis 1961. aastal tehtud uurimus näitab mõningaid selliseid ilminguid (Calais 1963). Samal ajal kogub inimene haigustega seotud kogemusi. See tähendab, et ta on ise patsiendi rolli sattudes võimeline "korrektselt" käituma. Iga inimene konstrueerib lapsepõlvest alates patsiendi rituaalide repertuaari ja arusaamad patsiendiks olemise kohta, mida vastastikuses seoses koos teiste ühiskonnaliikmetega kasutada või kõrvale heita. Need rituaalid pole vajalikud üksnes ühiskonna jätkumiseks, need tagavad ka haigele teatud turvalisuse ja innustavad teda terveks saama. Aktsepteerides ajutist ajatust, mille jooksul inimesel on lubatud käituda teistmoodi, saab patsient samas kinnituse, et ta kaasatakse rühma ja ta saab tagasi oma kontaktid ja tulevikuvõimalused, kui haigus on kord möödas. Oma subnormaalse käitumisega, millest osa on seotud tõelise jõuetusega, osa kultuurialase teadmisega sellest, mida patsiendi rollilt oodatakse, võib patsient suhtuda tervisemüüti väga suure respektiga. Ta kasutab seda kui positiivset ja saavutatavat eesmärki ning määratleb selle kaudu sotsiaalse ühtekuuluvuse ja jätkuvuse. Ideaalne patoloogiline draama on läbi mängitud ning see on saanud tasakaalustatud ja korrapärase lahenduse. 


\section{Patsiendid}

\section{Patsienditüübid}

Uurijad on olnud ravitsejatest palju enam huvitatud kui nende patsientidest. Ometigi sõltub ravitsejate tähtsus ühiskonnas otseselt nende suhetest patsiendi ja tema ootustega.

Patsient ja tema lähedased on huvitatud sellest, et haigus saadaks kontrolli alla. Haigestumine toob kaasa hulga otseseid ja kaudseid ebameeldivusi: valu, haigustunde, sissetuleku kaotuse, depressiooni, prestiižikaotuse, häbimärgistamise jne. Ometi võivad positiivsed aspektid, nagu kõrgendatud tähelepanu, kaastunne jms haigusega seotu teadlikult või alateadlikult tasalülitada patsiendi soovi olla terve.

Ravitseja patsiente võib liigitada lähtuvalt nende suhtumisest arstidesse ja oma haigustesse. Need rühmad esindavad erinevaid patsienditüüpe ja erinevaid motivatsiooniliike:

Tabel 1. Patsienditü̈̈bid ravitseja vaatepunktist

1. patsiendid, kellel eelnevalt on olnud kontakte arstiteadusega

1.1. rühma 1 kuuluvad patsiendid, kes arstiteaduse seisukohast ei ole haiged

1.2. rühma 1 kuuluvad patsiendid, kes arstiteaduse seisukohast on haiged

1.2.1. rühma 1.2 kuuluvad patsiendid, keda arstiteaduse seisukohast $e i$ saa ravida

1.2.2. rühma 1.2 kuuluvad patsiendid, keda arstiteaduse seisukohast saab ravida

1.2.2.1. rühma 1.2.2 kuuluvad patsiendid, kelle ravi ei ole arstiteaduse seisukohast rahuldav

1.2.2.2. rühma 1.2.2 kuuluvad patsiendid, kellele ravi ei ole nende endi või nende lähedaste arvates rahuldav

2. patsiendid, kellel eelnevalt ei ole olnud kontakte arstiteadusega

2.1. rühma 2 kuuluvad patsiendid, kes arstiteaduse seisukohast ei ole haiged

2.2. rühma 2 kuuluvad patsiendid, kes arstiteaduse seisukohast on haiged 
2.2.1. rühma 2.2 kuuluvad patsiendid, keda arstiteaduse seisukohast $e i$ saa ravida

2.2.2. rühma 2.2 kuuluvad patsiendid, keda arstiteaduse seisukohast võiks ravida

2.2.2.1 rühma 2.2.2 kuuluvad patsiendid, keda ei ole mingil viisil ravitud

2.2.2.2. rühma 2.2.2 kuuluvad patsiendid, kes ei ole saanud rahuldavat ravi saatekirja ega konsultatsioonil vormis

See patsienditüüpide mudel annab olukorrast selge ülevaate. Kui varem olid ülekaalus teise (2.) alajaotuse tüübid, siis tänapäeval saab rääkida peamiselt patsientidest, kes esindavad esimest tüüpi (1.). Millal see muutus aset leidis? Leidub hulgaliselt tõendeid, mis viitavad, et muutus toimus käsikäes teadusliku ja majandusliku murranguga 19. sajandi lõpul ja 20. sajandi alguses. Samal ajal leidis aset seaduslikult praktiseerivate arstide ületootmine - nad saavutasid oma eelkäijatega võrreldes palju paremaid tulemusi. Sel ajal usuti, et ravitsejate ajajärk jääb peatselt minevikku, kuid selle asemel on ravitsejad näidanud oma vastupidavust, kohandudes uute ühiskondlike struktuuridega (Rørbye 1976b). Mudelist selgub, et alati leidub patsiente, kes ei saa leevendust litsentseeritud ravijatelt, ja ravitsejad eksisteerivad senikaua, kuni neil on võimalus kohandada end patsiendi nõudmistega.

Eelnevalt selgus, et pole võimalik rääkida homogeensest ravitsejaskonnast ning mõistet ravitseja on keeruline määratleda. Patsienditüüpide mudel võib aidata määratleda erinevaid ravitsejatüüpe. Üksiku ravitseja puhul võib patsientide värbamine olla erinevatel perioodidel erinev, sõltuda tema edukusest, meetoditest, reklaamist jne.

\section{Patsiendi suhtumine haigusesse, tervisesse ja ravisse}

Patsiendi suhtumist haiguskontseptsiooni, ravisse ja tervisesse võib iseloomustada kui otsest huvideringi, mida mõjutab tema isiklik ettekujutus haigusega seotud positiivsetest ja negatiivsetest väärtustest.

Tüüpilisel patsiendil pole oma haiguse ja tervisega teaduslikku suhet. Kui ta tunneb end jätkuvalt väsinud ja haiglasena, ei lähe talle põhimõtteliselt korda teadmine, et tuberkuloosi ja maohaavandit ravitakse tal vastavalt skeemile. Tema eesmärgiks on eelkõige saavutada rahuldav tervislik seisund. See on suhteline mõiste, mida mõjutavad nii üksikisik kui ka kultuur.

Ühes populaarses patsientidele mõeldud raamatus, mille on kirjutanud praktiseerivad arstid, kirjutatakse järgmist: 
Ei ole võimalik piisavalt hoiatada selle eest, et sa populaarteaduslike raamatute ja artiklite põhjal ei üritaks ise välja selgitada, mis on sinuga lahti. Sa ei oska ise diagnoosi panna. Sinu soov valmistab sulle pettumuse! Proovi lugeda mõnda arstiteaduslikku raamatut sel ajal, kui oled täiesti terve. Isegi siis, kui sa oled terve, hakkavad sul tekkima kahtlused. Sulle hakkab tunduma, et sul on või on esinenud mitmeid raamatus kirjeldatud sümptomeid. Võib-olla märkad äkki, et vaatamata sellele, et oled täiesti terve, hakkab sul kuskilt valutama. Seega, kui sa oled haige, hoia end eemale "meditsiiniraamatutest". Isegi arstid peaksid konsulteerima teiste arstidega, kui neile tundub, et neil on mõni tõsine terviserike. On olemas palju näiteid arstide kohta, kes on oma haigust ise diagnoosida üritades, sattunud täielikult eksiteele (Claësson \& Mundt \& Søe 1974: 1314).

Raamatu autorid toetuvad raskelt saadud kogemustele ja jagavad õpetusi, kuidas vältida hüpohondria tekkimist. Paljud arstid teevad oma vastuvõtul sedasama ja on pettunud patsientide entusiasmi puudumises, kui neile öeldakse, et nad on tegelikult terved. Vastavalt WHO haiguse definitsioonile ei ole selline ravimisest loobumise viis õigustatud. Kui patsient ei tunne ennast hästi, tuleb teda ravida. Selles kontekstis tuleb aga siiski rõhutada, et see, kuidas patsiendid ravivõimalusi kasutavad, on suuresti mõjutatud nende sotsiaalsest ja kultuurilisest keskkonnast.

Üsna skemaatiliselt võib rääkida patsiendile iseloomulikult käituvate isikute kolmejärgulisest mudelist. Patsiendi kuvand vastab siin vaid osaliselt tegelikule arstiteaduslikule ettekujutusele. Esimeses järgus, kui haige tunneb end halvemini, on temal ja ta lähedastel suhteliselt tugev motivatsioon leida ravitseja või alustada uue ravi katsetamisega. See enda rohkem haigena tundmine võib tegelikult tuleneda põetud haiguse tüsistustest, kuigi haigus oli meditsiini seisukohalt taandunud. Kolmandas järgus, kui patsient tunneb end tervenenuna, võib rahvaarsti resp ravitseja külastamise motivatsioon olla suhteliselt väike. Keskmises järgus on käitumisstrateegiad väga varieeruvad. Rahuliku loomuga patsient võib oodata õiget aega, samas kui mõni teine võib kohe ravitsejaga konsulteerida.

Mitte ainult heaolu määr, vaid ka ajutine perspektiiv jääb selgusetuks. Kui palju aega möödub, enne kui patsient hakkab otsima alternatiivset ravi? Kas teatud mooduseid eelistatakse teistele? Oma roll on ka ravitseja ja patsiendi sotsiaalsel võrgustikul (Barnes 1954). Kui haige inimese lähedane sõber soovitab ravitseja poole pöörduda, saab suhe alguse kiiremini kui muudel juhtudel.

Mudel hakkab toimima, kui patsient teadvustab endale oma patsiendi rolli. See ei tähenda sugugi, et vastav isik oleks haige traditsioonilises mõttes, vas- 
tavalt arstiteaduslik-bioloogilisele haigusmääratlusele. Samuti ei pea see tähendama, et patsient otsiks arstiabi. Statistiline uuring on osutanud, et vaatamata haiglasele enesetundele ei konsulteeri arstiga kuni kaks kolmandikku inimestest, samas kasutavad teatud rühmad tervishoiuteenuseid sagedamini kui teised.

Arstiteaduslikus uurimustöös räägitakse seosest kolme nähtuse vahel: vajadus, nagu seda nimetavad meditsiinieksperdid; soovid, mis tähistavad inimeste tervisealast nõustamist, ning nõudmised, mis viitavad tervishoiuteenuste praktilisele vajadusele (Jeffers \& Bognanno \& Bartlett 1971: 46-63). Skandinaavia riikides, kus on suhteliselt hõlbus abi saada, on poliitilistes ringkondades arutletud eeskätt selle üle, kas tänapäeval eksisteerib meditsiiniteenuste ületarbimist. Taanis tutvustati 1974. aastal valitsuse ettepanekut, mille kohaselt tuli igal patsiendil tasuda 15 krooni visiiditasu. Ettepanek võeti hiljem siiski tagasi (Juul \& Sabroe 1977: 61). Sotsiaalteenuste ja -tervishoiuga tegelevates ringkondades on tehtud katseid selgitada välja nii võimalikku meditsiiniteenuste üle- kui ka alatarbimist. Rootsi uurimus osutab, et abivajajad on eelkõige mehed ja madalama sotsiaalse klassi esindajad (Bygren 1974).

Taanis Roskildes läbi viidud uurimuse kohaselt (vt eespool) oli kolmandik haigusjuhtudest seotud sissetuleku kaotusega. Nimetatud fakt puudutab eelkõige inimesi, kelle majanduslik seis on vilets. Pooled neist, kes polnud isegi vajadusel arsti poole pöördunud, seletasid seda raha- või ajapuudusega, samal ajal kui teine pool tõi põhjusteks eelnevad halvad kogemused, usalduse puudumise jms (Holst \& Scocozzo 1972). Neid andmeid võib tõlgendada erinevalt, kuid ei saa välistada, et arst, kes on kõrgema staatusega rühma liige, võib paremini toime tulla suheldes samasuguse taustaga patsientide ja nende lähedastega kui inimestega, kelle ühiskondlik, kultuuriline ja majanduslik seisund on talle võõrad. Tegelikult on nii, et võrreldes kõrgemasse klassi kuuluvate inimestega saavad madalamasse sotsiaalsesse klassi kuuluvad inimesed vaatamata kõigile toetustele vähem abi arstidelt ja tervishoiuasutustelt. See tuleneb sellest, et madalamad kihid kannavad ennast haigeks tunnistades sageli rahalist kahju.

Taani Tervishoiuamet (De Danske Sundhetsvæsen) on hoiatavalt märkinud, et tänapäeva tervishoiuteenuste kasutamise osas võib püstitada kolm põhjendatud hüpoteesi. Esiteks viitab paljugi sellele, et tervishoiuteenuste alatarbimine on seotud vananemisega. Nähtav tervishoiuteenuste tarbimise kasv on väiksem kui võiks arvata, arvestades vanusest tulenevaid erinevusi inimeste tervises (Juul \& Sabroe 1977: 61). Antud mõttevahetuse puhul on oluline märkida, et mõned arstid on hoopis vastupidisel seisukohal - paljude eakate inimeste tervislik seisund oleks parem, kui neid ei ravitaks ning on igati nor- 
maalne, kui neil on näiteks pisut kiirem pulsisagedus ja kõrgem vererõhk (Riisgård \& Weiss 1978). Teine suundumus on terviseteenuste ületarbimine naiste, eriti fertiilses eas naiste poolt.

Seda vaadete lahknevust võib vaid osaliselt seletada suremuse kasvuga ja seegi on vastuoluline põhjendus, sest kõigis vanuserühmades on meeste suremus naiste omast suurem (Juul \& Sabroe 1977: 61).

Selle ilminguga on hästi kursis ka ravitsejad, kelle klientidest moodustavad naised sagedasti enamiku. Selline käitumismudel on kahtlemata seotud soorolliga. Naistel on vähem kaotada. Neile on sagedamini lubatud nõrkuse väljanäitamine ning tugevate tunnete ja arvamuste väljendamine (vt Betækning 594: 1971; Betækning 715: 1974). Antud nähtust ei ole aga uuritud kaugeltki ammendavalt ja hinnangu andmisel tuleb arvesse võtta ka naiste töötingimusi. Kõik tänapäeva naised teevad pikemaid tööpäevi kui mehed. Kodust väljas töötava abielunaise tööpäeva pikkus on umbes üksteist tundi, samal ajal, kui need tööl käivad abielumehed, kes teevad kõige rohkem kodutöid, töötavad vaevalt üheksa tundi (Levevilkår 1976). Tööturul on naistele pakutavad tööd seotud eelkõige teisejärguliste aladega: nad on lihttöölised, väikeametnikud ja kontoritöötajad (Levevilkår 1976: tabel 2.0). Märkimisväärne hulk nende tööst on konveieritöö, mis on ühekülgne ja kujutab endast sageli individuaalset tükitööd. Sellega on seostatud mitmeid haigusi, ja kuigi ei saa teha kindlaid järeldusi nende tegurite patogeensuse kohta, tuleb tunnistada, et need võivad pikendada olemasolevat haigust ja takistada selle paranemist (vt Arbejdsmiljø 1974: erinevate kutseühingute liikmetele iseloomulike sümptomite tabel; $A r$ bejdsmiljø 1975: tabel 5.1: mitmesuguste sümptomite üle kaebavate naiste protsent kategooriates 'liiga kiire', 'veidi liiga kiire' ja 'sobiv' töökiirus; Levevilkår 1976: tabel 6.38: individuaalsete haigussümptomite sagedus vastavalt soole ja vanusele; tabel 4.12: peamised diagnoosid patsientidel, kes on vallandatud pärast 1972. või 1973. aastat).

Naiste töötingimused kodus ja töökohal on statistikale tuginedes seega raskemad ja põhjustavad mitmesuguseid väiksemaid ja suuremaid vaevusi. Ka tõsisemate haiguste korral on naistel suuremad probleemid. Invaliidsuspensionile määratuna on kehvemas olukorras naised, eriti abielunaised, kellel on raske saada keskmist või sellest suuremat pensioni. Invaliidsuspensionil olevate meeste arv on üleüldiselt suurem. Selles, et naised saavad tervishoiuteenuste kasutamisest rohkem kasu, mängivad rolli mitmed asjaolud ja tervishoiuteenuste ületarbimist ei saa kõrvale heita kui soorolliga seotud probleemi, mida on võimalik lahendada poisse ja tüdrukuid erinevalt kasvatades. 
Kolmas ja viimane nn tervishoidu puudutavate vajaduste ja nõudmiste vaheline nn lahknevus puudutab tervishoiuteenuste alatarbimist madalama sotsiaalse positsiooniga inimeste poolt.

Suremus näib kasvavat koos sotsiaalse staatuse langusega, sest madalama staatuse puhul väheneb tendents abi otsida. Selle tulemusel jäävad paljud ilma vajalikest tervishoiualastest nõuannetest, eriti neis rühmades, mis on sotsiaalselt kõige halvemas olukorras (Juul \& Sabroe 1977: 61).

Raske on öelda, kui paljud neist rühmadest eelistavad rahvaravitsejate abi, kuid vajadust nende järele on rõhutatud nii varem kui ka viimasel ajal. Nii arstid kui ka teised asjassepuutuvad inimesed on korduvalt avaldanud arvamust, et inimesed on teadmatuses, naiivsed ja harimatud ning kogu probleemi lahendab teabe jagamine. Vaieldamatud seigad osutavad aga sellele, et probleem on märksa mitmetahulisem nagu ka asjaolule, et tänapäevane tervishoiusüsteem on kohandatud eelkõige kõrgema sotsiaalse kihi vajaduste rahuldamisele (Koefoed \& Nielsen 1978).

Patsiendi suhtumine oma tervisesse on sama suhteline kui tema arusaamad haigusest ja ravist. Tänapäeval on tervise mõiste äärmiselt oluline. Rahvapärase arusaama kohaselt on parim kaitse haiguse vastu hea tervis. Ravitervishoid on kujunenud tegevusvaldkonnaks, millesse ka ravitsejad annavad suure panuse. Nõuannetega tervisliku toitumise, sobilike eluviiside, töötingimuste, stiimulite jms kohta on ravitsejad aidanud kaasa tänapäevase rahvapärase tervisemüüdi tekkimisele ning muutnud otseselt ja kaudselt meie igapäevaelu.

Eksisteerib kaubanduslik huvi, mis rõhutab arvamust, et iga inimene on potentsiaalne patsient ja ravi on muudetud tarbimisega samaväärseks. Tervis muutub kaubaartikliks, mida võib kõigile müüa, aga just sel määral - pange tähele! -, et inimesed õpiksid oma vajadusi tundma.

Etnomeditsiini uurimine selle rahvapärase tervisemüüdi seisukohalt on veel lapsekingades, kuid niipalju võib ütelda: põhimõtteliselt ei julgeks ükski inimene Skandinaaviamaades vastata jaatavalt küsimusele "Kas sa oled terve?". Teiselt poolt võiksid nad ilmselt pikalt vastata küsimustele: "Mida sa teed selleks, et elada tervislikult? ja "Mida sa võiksid teha, et elada tervislikumalt?"

Haiguse määratlemine on Skandinaavia kultuuris jõudnud tasemele, kus inimene teadvustab tervist kui vajadust ja sellekohaseid teadmisi levitatakse nii massimeedias kui ka inimestevahelises suhtluses. "Tervise tootmine" annab ka suurt rahalist kasumit. 


\section{Haige ja rahvaravitseja suhe}

Patsient, kes pöördub rahvaravitseja poole, on aktiivselt seotud oma haigusega. Ta mitte üksnes ei ela sellega, vaid proovib midagi ette võtta. See loob eeldused heaks tulemuseks. Patsient kogeb oma olukorda negatiivsena, ta vajab abi väljastpoolt ja otsib endale ravitseja, kes teda aitaks. Seeläbi annab ta ebateadlikult ravitsejale vähem või rohkem positiivse jõu, millest saab lisaväärtus. Kahtlev patsient on selle lisaväärtuse suhtes mõnevõrra ebakindel, kuid on sellele vaatamata motiveeritud, järeldades oma olukorrast, et viib läbi enda seisukohalt olulise katse. Seega on kahtlev patsient isegi enam motiveeritud kui äärmiselt enesekindel patsient, sest ebakindel patsient peab ületama ravitseja külastamiseks suurema takistuse.

Ideaalses olukorras tunneb patsient end tervenenuna, ravitsejale tasutakse, millega taastatakse tasakaal. Suhet võib iseloomustada ka teiste sõnadega: patsient on tarbija, kellel on vajadus või vaegus, ravitseja on kaupmees, kellel on lisaväärtus, ning turg on seotud haiguse, ravi ja tervise mõistetega.

Sellest seisukohast on ilmne, et see on turg, mis mängib pakkumise ja nõudmise seisukohalt otsustavat rolli. See on üks põhjusi, miks mitteametlike meditsiiniteenuste kirjeldamisel tuleb pidevalt pöörata tähelepanu ametlikule meditsiinile.

Soome põhjapoolsed isoleeritud metsarahvad, kelle lähim arst asus sageli päevateekonna kaugusel, kasutasid 19. sajandil eelkõige ravitsejate abi. Teisalt oli mitteametliku abi tarbimine sageli palju väiksem, sest haiguse mõiste maal erines haiguse mõistest linnas. Esines mitmeid haigusi, mille ravi oli inimestele teadmata ja mille vastu ei võetudki midagi ette. Nõudmine oli teatud määral kohandatud pakkumisega, näiteks lepiti lühema eluea ja laste suurema suremusega.

Teiselt poolt avab nõudmise ja pakkumise suhe õigele ravitsejale suurepärased väljavaated. Üks taani ravitseja kiitles 1880. aastatel, et on aasta jooksul ravinud vähemalt 16000 patsienti ehk ligikaudu 1\% Taani elanikkonnast. Samal ajal väitis ta:

Mind külastas eelmisel aastal ligikaudu 15000-16 000 inimest ja neist ehk 500 olid paljude aastate jooksul arsti juures käinud, sest nad ei usu, et sellest [st arsti juures käimisest - toim] on mingit kasu (Rørbye 1976a: 99).

See tähendab, et kuulus ravitseja tekitas vajaduse ravi järele nende inimeste seas, kes varem polnud selleks vajadust tundnud. Jules Romains on dramaati- 
liselt kirjeldanud, kuidas võib kogu kohaliku elanikkonna järsku haigeks muuta, et tark ravitseja saaks suurt rahalist kasu (Romains 1924).

Samasuguseid patsiente suunatakse ka tänapäeval sageli kõige kuulsamate ravitsejate juurde. Neist saavad "head patsiendid", sest nad suhtuvad ravitsejasse hästi ja on enne seda olnud nii terved, et neil pole oma probleemide lahendamiseks vaja olnud abi otsida. Üks või enam käiku ravitseja juurde võib taastada tasakaalu ja nad tunnevad ennast jälle hästi; teiste sõnadega - nad on jälle tagasi kolmandas etapis.

19. sajandil, kui Skandinaaviamaades oli tõsine puudus apteekritest ja arstidest, usuti, et šarlatanluse päevad on peagi loetud. Ravitsejad kaovad koos "ebausuga", mis tõrjutakse turult teaduse abiga. Kui tavainimesed saavad parema hariduse, võib kaduda ka nõudlus ravitsejate nõuannete järele. Isegi tolle aja kohta oli mõte liiga lihtsustatud. Ka 19. sajandil konsulteerisid paljud jõukad ja haritud inimesed mitteametliku arstiabi andjatega. Nagu patsienditüüpide loetelus viidatud, leidub patsientide rühmi, kes on nii tugevalt motiveeritud otsima alternatiivset abi, et ravitseja kasuks töötab kõik, ükskõik, millised ka ei oleks üleskerkinud probleemi tagajärjed. Üks taani kibestunud rahvaravitsejate vastane ja hilisem raviteenuste osakonna juht dr Speyer külastas 1838. aastal oma käe ravimise eesmärgil tuntud ravitsejat, kes tegeles luumurdudega, ja see lõppes range noomitusega ametivõimude poolt (Rørbye 1976a: 87-88). Alati leidub ka patsiente, kes ei anna alla. Teiste sõnadega, on näha, kuidas patsientide ja ravitsejate ootuste intensiivsus varieerub ühest ravisituatsioonist teise. Äärmuslikuks näiteks võib tuua samasuguse ravitseja, nagu juba eelkirjeldatud Taani šarlatan, kes tekitab oma lähiümbruse patsientides vajaduse ravi järele. Teise äärmusena võivad patsiendi väga kõrged ootused ajendada teda looma lähemaid suhteid ravitsejaga, kes omakorda püüab sellest rollist hoiduda (nt Rørbye 1976a: 150).

Neid suhteid ei saa pidada püsivateks. Patsiendi ootused võivad erinevate ravitsejate puhul ja erinevates olukordades varieeruda. Sama moodi võib ravitseja olla erinevate patsientide suhtes aeg-ajalt vähem või rohkem domineerivas rollis või siis asetada ennast patsiendiga peaaegu samasse situatsiooni. Ka oma ametiaja eri etappidel võib ta olla erinevates suhetes. Eriti oluliseks on ravitseja rolli muutnud viimasel ajal massimeedia, mis on etnomeditsiini käsitlenud "kuuma teemana". Taani turu-uuringute instituudi analüüsi kohaselt eelistavad inimesed lugeda kohalikke uudiseid; teisel kohal olid artiklid tervisest ja haigustest (Münster 1977: 30). 


\section{Ravitseja}

\section{Ravitseja suhe haiguse, tervise ja raviga}

Korduvalt on rõhutatud, et ravitsejad moodustavad kireva rühma. Samasugune mitmekesisus eksisteerib ka ravitsejate meetodites ning suhtumises tervisesse ja haigusse.

Kindlatel ravitsejatel on kindel hulk teadmisi ja neid ei huvita kogu situatsioon tervikuna. Nii oli see Taanis nn luumurruarstidega, kes 5. septembri 1794. aasta määruse kohaselt said õiguse ravida nikastusi, luumurde ja lihtsaid haavu. Ametlikult kehtis see seadus 1934. aastani (Carøe 1920; Rørbye 1976a: 259-260). Sajandite jooksul on ravitsejad spetsialiseerunud ka teistele haigustele, nagu migreeniga peavalud, luuvalud ja soolatüükad. Tänapäeval keskenduvad arvukad ravitsejad suitsetamisest vabastamisele ja kaalu langetamisele. Üks eriline valdkond, mille eest vanasti karmilt karistati, on raseduse katkestamine. Mõned ravitsejad kasutasid mõningaid ravimtaimi ja ravimeid, et kutsuda esile "hilinenud kuupuhastust", mida sageli peeti viljatuks katseks kuritegu kergendada, samas kui hilisemal ajal otsiti olukorrast väljapääsu pseudokirurgilises sekkumises (vt Frøiland et al 1976).

Ravitsejad on sageli spetsialiseerunud teatud meetoditele ja võtetele. Mõned neist on kas varem või teistes ühiskondades leidnud kasutuse ka arstiteaduses. Populaarsed meetodid, nagu mesmerism ja homöopaatia, tegid 19. sajandil Euroopas võidukäiku (Gotfredsen 1973: 314-317; vt Rørbye 1976a: 261, 269). Ametlikult kaotasid nad Skandinaaviamaades tähtsuse 20. sajandi jooksul, kuid neid kasutatakse tänini laialdaselt. Mitmeid ravivõtteid, nagu akupunktuur, mesmerism ja massaaž kasutavad nii ametlikud kui ka mitteametlikud arstiabi andjad, samas kui arstid pole kunagi kasutanud näiteks silma vikerkesta järgi diagnoosimist, tsooniteraapiat, heliteraapiat jpt meetodeid, mis on kasutusel ravitsejate seas või inimeste koduses ravis. (Teavet nende meetodite kohta võib leida: Broch 1954; Bø 1972; Clausen 1936; Eagle 1980; Munkebo \& Olesen 1971; Johansen 1912; Møller 1942; Sand 1930; Tillhagen 1958.)

Ravitsejad, kes kasutasid oma patsientide ravimisel erilisi meetodeid, püüdsid sageli saavutada olukorrast paremat ülevaadet. Haigust tajuti fenomenoloogilisest seisukohast lähtudes sageli kurja jõuna, mis tuli saada kontrolli alla. Järelikult polnud patsiendi kohene ravimine alati tarvilik. Ravitseja võis ka kaudselt aidata kaasa patsiendi tervenemisele, võideldes kurjade jõudude vastu või kaasates häid jõude. Ravitseja pidi oma meetodeid meisterlikult valdama ja tema ettevalmistus sarnanes oskustöö õppimisele. Õpipoisist ravitse- 
ja töötas aastate kogemusele toetudes välja ravimeetodid ja vastavalt sellele kujunesid ümbruskonna ootused ravitseja oskuste suhtes. Paljud ravitsejad said oma teadmised perekonnaliikmetelt või ükskõik kummast soost õpetajatelt. Nad talletasid mällu või kirjutasid oma raamatukestest üles maagilisi vormeleid, neil oli lubatud minna kaasa patsiente külastama ja nad said vanemat ja suuremate teadmistega ravitsejat jälgida haigust "diagnoosimas", ravimtaimi kogumas, jalahaava "pistmas", haiget last mõõtmas, varastatud asjade tagastamist mõjutamas jne (Tillhagen 1958; vt Rørbye 1976a).

Sel viisil tekkisid sageli erilised ravitsejate dünastiad, kes tegutsesid paljude põlvkondade jooksul kohalike rahvaarstidena (Rørbye 1976a: 49 jj, 88 jj, $93 \mathrm{jj}, 114 \mathrm{jj}, 157 \mathrm{jj}, 181 \mathrm{jj}, 186 \mathrm{jj}$ ).

\section{Kuidas teavet levitati?}

Vanas talupojaühiskonnas oli ravitseja inimene, keda teati paljude erinevate rollide tõttu, mis näitas tema otsest seotust kohaliku kultuuriga. Oli ravitsejaid, kelle üle visati nalja (nt Rørbye 1976a: 60), ja teisi, keda inimesed kartsid ning kellele vaadati alt üles (nt Rørbye 1976a: 28). Ravitsejad olid osa kohalikust kogukonnast, keda inimesed tundsid ja kellega suheldi, olenemata sellest kas oldi tema patsient või mitte (vt Henningsen 1978).

On väga suur erinevus, kas tegu oli kogukonda integreerunud ravitsejatega, kelle kohta levis teave suust suhu ja kes olid kohaliku ühiskonna osa, või massimeedia loodud ravitsejatega, kes on eelkõige tänapäevane nähtus. Viimaseid tutvustatakse üleriigilistes ja kohalikes ajalehtedes, nädala- ja kuukirjades, raadios ja televisioonis. Patsientide esimene kontakt nendega toimub massimeedia vahendusel, mitte suulise teabe kaudu, mida antakse edasi ühelt inimeselt teisele.

Paljud ravitsejad tegelevadki klientidega ainult teisese kontakti kaudu. Etnomeditsiini alal tegutsevad paljud postimüügiettevõtted (nt Rørbye 1976a: 200). Need tekkisid kõigepealt 19. sajandil Saksamaal, kust eksporditi suurel hulgal keelatud ja salajasi ravimeid Skandinaaviamaadesse, kus ametnikud püüdsid ebaõnnestunult nende müüki piirata. Ravimite nimed vahetusid nii kiiresti, et polnud suurt mõtet koostada nimekirja turul olevatest ravivahenditest. Täidesaatvad võimud ei suutnud tootjaid tabada, juhuslikult saadi kätte mõned üsna tähtsusetud maaletoojad (nt Rørbye 1976a: 78-79). Postimüügi klientidel oli harva võimalust saavutada ravitsejatega isiklik kontakt. Patsient pidi end ise ravima raamatutes, voldikutes ja kirjades leiduvate instruktsioonide põhjal või medikamentide ja ravimite abil. 
Isikliku suhtluse, massimeedia ja teiste teabekanalite tähtsus ravitsejate huvikeskmesse tõusus on veel lahendamata. Võib-olla leidub tänapäeval väike tugevalt motiveeritud rühm inimesi, kes proovib peaaegu kõike? Kui nii, siis mis sunnib neid välja nuhkima just ravitsejaid? Kas on tegemist mõne mõjuvõimsa rühmaga, kes, omades majandushoobasid, püüab upitada uut ravitsejat järjele?

Teave seesuguste ravitsejate kohta ei levi mitte ainult pidevalt ja üha laienevas sotsiaalses võrgustikus (nagu ringid vee peal), vaid ka laushüpetena. Kohtuvaidlused on sellistele hüpetele sageli kaasa aidanud. "Superravitseja" vaevalt ametlikke sanktsioone kardab, pigem võib ta kasutada seda reklaamiks ja märterluseks.

\section{Milliseid jutte inimesed räägivad?}

Välitöödel ja arhiivis töötades on etnomeditsiini uurijad pidevalt seatud vastamisi tõsise probleemiga, et on väga raske või koguni võimatu saada andmeid ravitsejate kohta. Mis puutub faktidesse, tuleb sageli leppida kiriku meetrikaraamatutest, kohtumaterjalidest, töölubadest ja teistest dokumentidest saadava teabega.

Rahvajuttudes peegeldub teistsugune reaalsus. Näiliselt tegeldakse seal kogemustega, mille on saanud kas jutustaja või teised inimesed ja tegemist on justkui tõestisündinud lugudega. Ent juba 1931. aastal täheldas rootsi folklorist Carl Wilhelm von Sydow, et isegi kogemuste seletused võivad muutuda täpselt sama psühholoogilise protsessi mõju all, mis on kujundanud pärimuslikku ainest ja sageli laenatakse rohkem või vähem alateadlikult just vanale traditsioonile iseloomulikku (Sydow 1931: 96). Ta järeldab:

See, mida räägitakse igapäevaelu sündmustest ja oma kogemustest, ei ole väga oluliselt erinev pärimuses edastatud samalaadsest materjalist (Sydow 1931: 96).

Seega on meil antud juhul tegemist rikkaliku ja peaaegu puutumatu uurimisvaldkonnaga Skandinaaviamaades. Igapäevaelu sündmuste uurimine on unarusse jäetud - folkloristid on eelistanud uurida muinasjutte, muistendeid, vanasõnu, mõistatusi, nalju ja teisi paremini defineeritud suulise pärimuse žanre.

Seetõttu võib siinkohal juttu teha vaid sellest, mida olen praeguseks suutnud kindlaks teha. Siin on tegemist igapäevaelu puudutavate etnomeditsiiniliste juttude üldisema analüüsi sissejuhatava osaga. Jutud ravitsejatest ja ravimisest, mis hõlmavad osa etnomeditsiinialaseid kogemusi käsitlevatest jut- 
tudest, ulatuvad tagasi kaugesse minevikku; tegemist on väga laialdaselt levinud pärimusega, mis on siiani väga elujõuline. Isiklik haiguskogemus on stereotüüpne ja selle kulg on vastavalt patoloogilisele draamale jaotatud erinevateks etappideks (vt eespool).

See on rahvapärimus, mida kogutakse välitöödel. Kui küsida, kas inimesed tunnevad mõnda ravitsejat või alternatiivset meetodit, antakse eitava vastuse asemel sageli kaudne vastus mõne haigusega seotud jutu vormis. Inimestel on konkreetsete faktide asemel teadmised, mis aktualiseeritakse dramaatilises vormis. Sama võib sedastada rahvaluulearhiivis leiduva materjali põhjal. Harva saadakse teavet ravitsejate meetoditest ja ettekirjutustest, kuid palju sagedamini kõneldakse juhtumitest ja sündmuste jadadest, tõlgendustest ja tunnetest. Väike osa etnomeditsiinilistest kogemustest on kogutud muistendite vormis, et talletada üleloomulikkust. Paljud neist juttudest on rändmuistendid, mida on kord räägitud ühe ja siis jälle teise ravitseja kohta (nt Rørbye 1976a: 29). Mitmed hästituntud ravitsejad on olnud selliste rändmuistendite seisukohalt otsekui tõelised "magnetid", mis igati aitas kaasa nende tuntusele (nt Rørbye 1976a: 98).

\section{Etnomeditsiinilised jutud igapäevaelust. Esimene põhitüüp: ravijutud}

Kõige tavalisem etnomeditsiinialane jututüüp kirjeldab ravimist. Siin mängitakse läbi patoloogiline draama, mis lõpeb tasakaalu saavutamisega. Peategelasteks on kangelased, kelmid ja abistajad. Esimeses alarühmas (1.1) on jutu kangelaseks hea patsient ning kelmi roll on antud ametivõimudele, tervishoiusüsteemile, halbadele arstidele või harvadel juhtudel ka halbadele ravitsejatele. Abistajaks on hea ravitseja, kelle ravi on edukas. Teises alarühmas (1.2) on kangelane hea ravitseja, keda ümbritseb hulk enam-vähem häid patsiente, kes tõendavad tema võimeid või oskusi. Eraldi jututüüp tegeleb patsientidega, kes ei ravi end nii nagu peaksid või leiavad tee ravitseja juurde liiga hilja. Nende juttude patsientidele on antud kelmirollile sarnane osa. Nad lasevad või lasknud käest oma võimaluse ja seepärast ei too ravitseja kangelaslikud pingutused kaasa mingeid muutusi. Sümpaatia jääb nendes juttudes endiselt ravitseja poolele.

Ravijuttudes leidub palju probleemidest ajendatud olukordi ja aspekte; tasakaalu saavutamine pakub vähem huvi. Muidugi on see vajalik jutu kokkuvõttena, aga ei ole iseenesest mõjus. Selles osas sarnanevad kogemusjutud rahvajuttudega. Paljud neist lõppevad lausega "ja nad elasid õnnelikult, kuni surm neid lahutas”, kuid üheski ei arutleta õnne tähenduse üle. Patoloogilise 
draama puhul tähendab see seda, et aset leiab segaseid aspekte sisaldav intensiivne arutelu, kuna aga teist osa esitatakse vaid väga objektiivselt. Ravijutud kinnitavad tervisemüüti ilma seda vaidlustamata ja toetavad sel viisil mõningaid sotsiaalpoliitilisi eesmärke.

\section{Etnomeditsiinilised jutud igapäevaelust. Teine põhitüüp: haigusjutud}

Teise etnomeditsiinialaseid kogemusi sisaldavate juttude põhitüübi moodustavad haigusjutud. Tegemist on katkestatud patoloogilise draamaga, kus tasakaalu ei saavutata. Peategelasteks on halvad patsiendid ja praktiseerivad arstid, kes ei suuda probleeme lahendada. Kui jutu peakangelaseks on halb patsient (2.1), moodustab haigusjutt harva terviku. Öeldakse, et see on pigem negatiivne lisand, mis täiustab viimistletud lugu $(2.1+1)$. Selline kombineeritud tüüp on väga levinud nii varasemas kui ka hilisemas pärimuses, kus jutustaja võib mitmeid kordi liikuda edasi-tagasi positiivsete ja negatiivsete tasandite vahel, tajudes väga tundlikult, mis on põnev.

Negatiivsel tasandil on kõik lootusetu ja perspektiivitu. Dramaatilistel eesmärkidel kujutatakse olukorda nii kohutavana kui võimalik. Ma istuksin tänaseni ratastoolis või oleksin hoopis surnud, on üks tüüpilistest lausungitest (Ude og Hjemme 1973/35: 10-14). Sageli mõjutab jutu üldist iseloomu see, kui jutustaja ütleb, et tegemist oli vähktõvega: kirjeldatakse hirmsaid valusid, inimese võimetust elatist teenida ja, mis oluline - vihjatakse arstidele, kes ei suuda enam patsienti aidata ega saa millestki aru.

Positiivsel tasandil on kõik täis lootust tervenemisele ja õnnele. See, mis jäi negatiivsel tasandil lahendamata, saavutab siin tasakaalu. Uuesti saavutatud tasakaalu tuleb vaadelda konflikti valguses ja seetõttu on kaks tasandit omavahel seotud sageli isegi pisimate peensusteni. Arstid tegelevad ravimisega pikka aega, kuid tulemusteta; ravitseja tegutseb kiiresti ja edukalt: Arstid võitlesid poolteist aastat selle väikese tüdruku päästmise nimel! Seejärel pöördus tema perekond hea ravitseja poole: Juba esimene ravikord oli edukas kaks kuud hiljem oli ta terve. See on näide, kuidas esitatakse üht tüüpilist haigusjuttu (Femina 1973/36: 25). Teistes juttudes lisab jutustaja, et ravist on möödunud juba palju kuid või aastaid ja patsient on ikka tervise juures.

Kui haigusjuttudes on peategelaseks ja negatiivseks kangelaseks (2.2) kelm, võib katkestatud patoloogiline draama moodustada tervikliku jutu. Sellest võib saada nn kelmusjutt. Nii seaduslikud kui ebaseaduslikud arstiabi andjad võivad olla asetatud kelmi rolli; mõnikord on lood ühendatud (et efekt oleks suurem) ravijuttudega, milles hea ravitseja või arst olukorra lahendab $(2.2+1)$. 


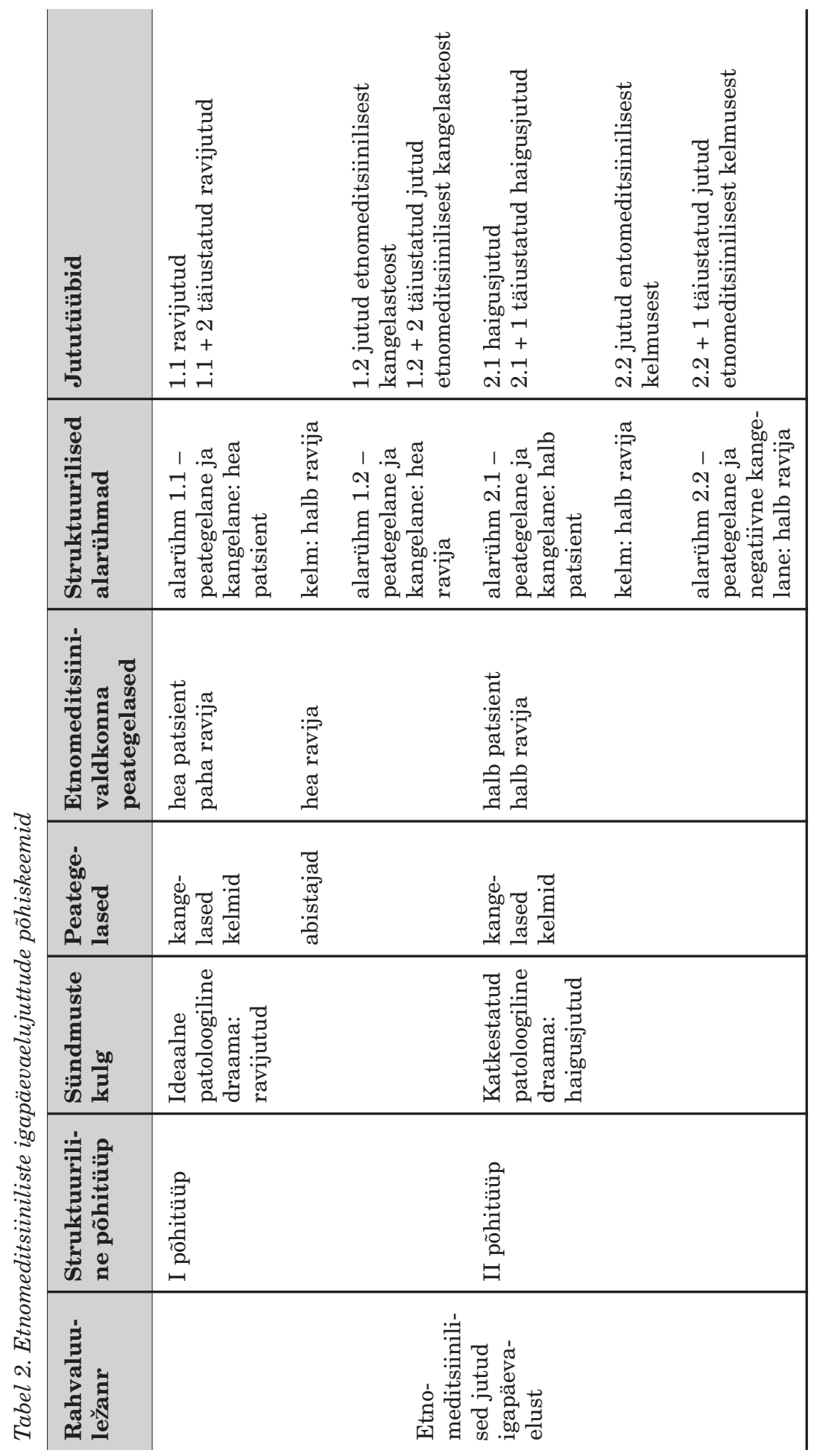


Enamik ravitsejaid oskab rääkida lugusid halbadest arstidest. Üks nende lemmiklugudest räägib sellest, kuidas arst ise või tema perekond tuleb igasuguse lootuse kadumisel ravitsejalt abi otsima (nt Rørbye 1976a: 39). Teistes lugudes visatakse arstide üle nalja ja räägitakse nende arstiteaduslikest faux pas'dest. Mõnes jutus võib leiduda ka tõetera. Mõnikord on tervishoiuga tegelevad ametnikud asjaga seotud arstilt aru pärinud või on vaidlusküsimused üles kerkinud kohtuprotsessi käigus (nt Rørbye 1976a: 187-188). Kuid enamikul juhtudest on võimatu tõestada, kas tegemist on tegelikkuse või väljamõeldisega. Etnomeditsiinilisest seisukohast pole võtmeküsimuseks see, kas jutt vastab tõele, vaid pigem see, kas lood on populaarsed ja kas neid peetakse huvitavateks. Teisisõnu kas nad puudutavad olulisi rahvapäraseid tõekspidamisi ja norme.

Arstid, professionaalsed arstiabi andjad ja teised ravitsejatele vastanduvad isikud oskavad samuti jutte rääkida. Ühesõnaga - need kaks rühma lõikavad kasu paljudest negatiivselt ja stereotüüpselt teineteise pihta sihitud avaldustest, tundmata sageli tegelikku olukorda. Ravitsejaid kujutatakse šarlatanide ja tüssajatena, kes kasutavad inimesi ära ja meelitavad neilt valede ettekäänete abil raha välja. Nendes lugudes asetatakse ravitsejad eriti halba valgusesse sellega, et jutustaja rõhutab, kuidas ravitsejad astuvad vastu ajast kantud ja rahva seas sügavalt juurdunud väärtustele, nagu terve mõistus ja inimeste omandi austamine (nt Piø 1976). Ka neid jutte ei saa ajaloolises mõttes kuigi tõesteks pidada, siiski võib osa neist olla ka ametlikult dokumenteeritud.

Negatiivsest kangelasest rääkivad rahvapärased haigusjutud aitavad kaasa eelarvamuste tekkimisele ja püsimisele seaduslike ja ebaseaduslike ravijate vahel. Need eelarvamused on "kasulikud" seetõttu, et nad kaitsevad teatud piire, mida ühiskond tahab säilitada. Mõned ravijad - arstid - saavad raha ja teisi toetusi, kuid on vastutasuks sunnitud alluma järelevalvele ja ametlikele eeskirjadele. Teisi ravijaid - rahvaravitsejaid - peetakse kokkuleppeliselt lindpriideks. Sellest hoolimata lubatakse neil tegutseda ilma ametkondade märgatava vahelesegamiseta, kuni ei juhtu äpardusi või õnnetusi.

Sellist ühiskondlikku topeltstandardit tuleb vaadelda laialt levinud arvamuse valguses, mis toetab paljus haiguse ja tervisega seotud illegaalseid ravivõtteid. Mitmes mõttes on ravitsejate antav abi muudetud millekski aktiivseks, sõltumatuks, demokraatlikuks ja eriti "rahvapäraseks" võrreldes ametliku arstiabiga.

Massimeedias pööratakse ravitsejatele sageli tähelepanu ja rõhutatakse nende ravi perspektiivikust, selgitades selle olulisust keeruliste haigussituatsioonide lahendamisel. Üksikisik peab mõistma oma olukorda ja säilitama selle 
suhtes aktiivse hoiaku. Tegemist on tüüpilise juttudes esineva kasvatusliku teemaga: Veidi lootust on alati - kui inimene ise midagi ette võtab (Ude og Hjemme 1973/35: 13). Ja veidi edasi: Olen veendunud, et saan terveks, kui ma ainult pidevalt seda endale sisendan. Selle põhjapaneva seisukoha tõestuseks võiks tuua hulgaliselt näiteid. Nii nagu nädalalehtedes ilmuvates lugudeski, on probleemid muudetud isiklikeks (Rørbye 1970). Olukordi võib lahendada või vähemalt parandada juhul, kui inimene seda ise soovib. Arste ja tervishoiutöötajaid - nende juttude kelme -, kujutatakse leppimatute, kangekaelsete ja enamasti mitte kuigi tarkadena. Täpsem analüüs peaks välja selgitama, milliseid normirikkumisi neile tegelikult omistatakse ja kas eelnimetatud väärtuste seas võib täheldada mingeid ajaloolisi muutusi. Vahel mainitakse arste ja teisi ametlikke ravijaid ka positiivses valguses, kuid selle põhjuseks on enamasti nende avatud suhtumine alternatiivsetesse ravivõimalustesse. Nädalaväljaannete kriitika ei ole suunatud üldiste sotsiaalsete probleemide lahendamisele, nagu patsientide kehvad töötingimused, füüsiline kurnatus, tööturult väljatõrjumine jne. Haigust kujutatakse isikliku probleemina, mida teised suudavad mõista ja millele kaasa tunda, mitte kunagi aga sotsiaalse küsimusena, mis nõuaks ühist tegutsemist ja avalikku protesti (vt Diderichsen 1977; Jensen \& Jensen 1976: 264).

Nädalalehtedes avaldatakse kiitvaid artikleid sellest, kuidas inimesi ravitakse. Tavaliselt on tegemist informatiivse materjaliga, mis kajastab tegelikke inimesi ja sündmusi, kuid oma ülesehituselt ja eesmärkidelt on need väga lähedal ilukirjandusele (Rørbye 1974). Jutud on muudetud põnevateks, meelelahutuslikeks ja dramaatilisteks - igapäevasteks imelugudeks.

Sõna ime ja teised sarnased mõisted on massimeedias kujunenud võtmesõnadeks. Nädalalehtedes ja -ajakirjades ilmuvates juttudes on suhtumine imedesse klassikalistest religioossetest kirjeldustest erinev. Asi pole niivõrd sõnumi levitamises, kuivõrd lugeja haaramises jutu sündmustesse. Piiblis ja teistes religioossetes lugudes on kesksel kohal ja tõeliseks eesmärgiks jumalik aspekt. Populaarsemate juttude ja raamatute puhul võib näha, kuidas neid lugusid muudetakse põnevamaks - ja sageli ka vähemharivaks. Massimeedias levivate ravijuttude abil on lugejatel eriti soodne võimalus üht-teist läbi elada ja ajutiselt oma probleemid unustada. Siit leiavad nad olukordi, millega samastuda, ja inimesi, keda imetleda ja kellest unistada (Rørbye 1970).

Etnomeditsiinilistes imelugudes igapäevaelust ei ole kohta tähtsatel sõnumitel ja sügavamõttelistel religioossetel arutlustel. Otse vastupidi, ime on demüstifitseeritud. Võib-olla tajuvad patsiendid kogu olukorda mingil määral imelisena, aga jutustaja väidab, et ravitseja on tegelikult tavaline inimene ja ka ravi on tavapärane. Ime on muudetud millekski mõistuspäraseks. Patsient 
kogeb sündmusi metatasandil, jutustaja aga annab sündmusi edasi kui reaalsust. Sellise tõlgenduse abil muutub ravitseja veelgi imetlusväärsemaks, sest jutustaja edastatud kogemus osutab, et ravitseja valdab tõsiselt võetavat meetodit või oskust, mis võib inimesi aidata. Professionaalsed vestekirjanikud eemaldavad müstilised aspektid ja muudavad ravitseja seeläbi rahvale - järelikult ka uutele patsientidele - lähedasemaks. Massimeedia ravijuttudes leiduv sisemine vastuolu - ühelt poolt realistlikuma ja mõistuspärasema tõlgenduse ja teiselt poolt imepärase ja müstilisega manipuleeriva metatasandi vahel - moodustab pingevälja, millel on oma sisemine dünaamika. Patsiendile ja tema perekonnale võib sellistel pingetel olla motiveeriv ja ergastav mõju, millest võib ravisituatsioonis olla palju abi.

\section{Ravitseja ja ühiskond}

Ravitsejad on osalised sotsiaalses konfliktis - see avaldub kahepalgelises suhtumises nendesse. Ametlikult on nende tegevus seadusevastane, aga praktikas võib enamik ravitsejatest tegutseda suhteliselt segamatult.

Vanasti jäid ilma meditsiinilise abita paljud maainimesed ja vaesed (Rørbye 1976b: 213). Tõenäoliselt esines arstiabi alatarbimist ka vanurite hulgas. Paljud tõendid osutavad, et tänapäevased vastuolud põhinevad traditsioonilisel suhtumisel sellesse, mida inimesed usuvad olevat võimaliku teha nende igapäevaste vaevuste vastu, eelkõige aga sellel, mida nad võimalikuks ei pea. Meditsiiniteenuste ületarbimist naiste hulgas ei saa aga ajaloolisesse perspektiivi paigutada. Ainuüksi kahe viimase põlvkonna jooksul on naiste keskmine eluiga märgatavalt pikenenud, sest varem surid paljud naised seoses raseduse ja sünnitamisega, ilma et neil oleks olnud arstiga mingit pistmist.

Sellised tingimused lõid ravitsejatele soodsa pinnase tegutsemiseks. Ühiskonnale ei maksnud see midagi, inimesed läksid nende juurde omal vastutusel ja kui midagi juhtus, võidi käivitada seaduslik masinavärk. Järk-järgult muutus arstide võrk tihedamaks ja võistlus ravitsejatega ägedamaks. 19. sajandil kogesid paljud noored arstid, et piirkondades, kus tegutses üks või enam populaarset ravitsejat, oli väga raske oma praksist alustada (nt Rørbye 1976: 105). Arstidega võeti alles siis ühendust, kui enam mitte midagi polnud võimalik teha ja nende heale nimele ei mõjunud hästi, kui suur hulk patsientidest lühikese aja pärast suri või pidi läbi tegema amputatsiooni või mõne muu tõsise ja piinarikka operatsiooni.

Järk-järgult usk arstiteadusse kasvas ja kõikide tõendite järgi otsustades mängis selles olulist osa hügieenitaseme tõus. Paljud arstid tegutsesid selle 
nimel, et inimesed kasutaksid puhtamat õhku ja vett, paremaid elutingimusi, vaheldusrikkamat ja toitvamat sööki, arstid õhutasid muutusi töökeskkonnas jne. Paljud haigused, mis varem olid saanud saatuslikuks elanikkonna vähemkindlustatud kihtidele, kaotasid 19. sajandi lõpus ja 20. sajandi alguses oma tähtsuse. Väiksem suremus laialt levinud haigustesse, nagu tuberkuloos, skorbuut, tüüfus, rahhiit jne, ei tulenenud mitte meditsiini plahvatuslikest võimalustest ega teaduslikest saavutustest, vaid see oli seotud hoopis hügieenialaste teadmiste levikuga (Christensen 1976: 13-16).

Üleminekuperioodil laienes ka ühiskondlikult kontrollitud terviseasutuste võrk. Majanduslikud võimalused paranesid ning arstide, haiglate ja teiste terviseasutuste arv kasvas märkimisväärselt. Nii ametivõimud kui ka haritud inimesed olid seisukohal, et ravitsejad kaovad iseenesest, sest inimesed muutuvad targemaks ja nõuavad paremaid võimalusi, kuidas tervishoiuteenustest rohkem kasu saada, vaatamata sellele, kus nad elavad või milline on nende sotsiaalmajanduslik seisund. Sel ajal ei mõistetud, et ravitsejad ja patsiendid muutuvad samuti. Ent nad muutusid, ja see avaldus järjest suurenevas kommertsialiseerumises, ravimeetodite muutumises ja kõike eelnevat arvestades - uutmoodi lepingutes, mis sarnaselt riiklikule tervishoiusüsteemile sisaldasid endas nii mõistuspärasust kui ka tsentraliseeritust ning muutusid rahvusvahelisemateks. Kogukonda integreerunud rahvaravitsejad, varem arsti suurimad vaenlased, kaotasid senise tähtsuse. Neist sai üks rühmitus paljude seas. Kõige rohkem kaotasid maagiaga tegelevad ravitsejad, ning tekib küsimus, kas see polnud hoopis kahjulik psühhosomaatiliste haigustega patsientide seisukohalt, kellel on raskusi abi leidmisega kehtiva ametliku arstiabi raames.

Ei saa aga öelda, et inimkonna üldine tervislik seisund oleks tänapäeval paranenud. Skandinaaviamaade heaoluühiskonnas on patoloogiline pilt aga hoopis teistsugune. Seda näitavad esiteks surmapõhjuste statistika, arstiga konsulteerimise põhjused, haiglas ravitud haigused ja tõved ning muud põhjused, millega inimesed põhjendavad töölt puudumist. Kui tuberkuloos ja nakkushaigused põhjustavad ligikaudu $1 \%$ surmajuhtumitest, siis südamehaiguste, pahaloomuliste kasvajate ja õnnetuste hulk on dramaatiliselt kasvanud (Dødsårsagerne i Danmark 1973: tabel 3).

Taani sotsiaaltervishoiu uurija Vagn Christensen sõnastas olukorra järgnevalt:

Haigustega seotud olukordi tuleb meie ajal tõenäoliselt käsitleda samuti nagu näiteks tuberkuloosi eelmisel sajandil. Raviks kasutati erinevaid meetodeid, mille kohta tänapäeval teatakse, et need polnud eriti efektiiv- 
sed, vaid eelkõige rituaalsed. Haigus kadus vaid juhul, kui kadusid ühiskondlikud eeldused selle tekkimiseks, st toit, elu- ja töötingimused ning muud tingimused paranesid (Christensen 1976: 19).

Sotsiaaltervishoiu keskustes jätkatakse arutelu teemal, et ühiskond on vastutav tingimuste eest, milles inimene peab elama. Vastavalt sellele kuulub arstide tööülesannete hulka ka teabe kogumine inimeste sotsiaalse olukorra ja patoloogiliste tingimuste vahekorra kohta. Nii saavad nad poliitikuid varustada lähtematerjaliga, mille põhjal on viimastel võimalik kujundada oma prioriteete (vt Gregersen \& Bech et al 1976: 193-194). Taani arst Peter Ege on veelgi kriitilisemal seisukohal:

Suure meditsiinimasinavärgi taga varjame asjaolu, et meil puuduvad igasugused alternatiivsed ravivõimalused ulatuselt kõige levinumate haiguste, st südame-veresoonkonnahaiguste, mitmesuguste vähkkasvajate, psühhosomaatiliste ja närvihaiguste, ning nii noorte kui ka vanade seas levinud keelatud ainete kuritarvitamise, laste ja noorte käitumishälvete ja närvihaiguste puhuks. Neid haigusi võib võita otstarbekalt läbiviidud profülaktilise tööga, mis ennekõike nõuab suuri muudatusi ühiskonnakorralduses (Ege 1977: 74-75).

Sotsiaaltervishoiu spetsialistide uurimistöö on selge poliitilise orientatsiooniga, mis sarnaneb mitmes aspektis ravitsejatelt lähtuva kriitikaga. Oma oponentidena näevad nad poliitilisi rühmitusi, ametivõime, loodud tervishoiuasutusi ja meditsiinitööstust. Mõlemad rühmad avaldavad rahulolematust heaoluühiskonna haigusõpetusega ja peavad end haigete eestkõnelejateks. Nad küsivad, miks peaksid patsiendid olema rahul sellega, et nende olukorra parandamiseks ei võeta midagi ette, miks nad ei saa vajalikku ravi. Ravitsejad tegutsevad vastavalt nende patsientide loodud tingimustele. Nad on eelkõige huvitatud isiklike vajadust rahuldamisest ja konkreetsest nõudlusest. Võibolla arutlevad nad vähem selle üle, kas see on arstiteaduslikult õige või vastavuses ühiskonna huvidega. Ravitsejate süüdistamine on liialt lihtsustatud, sest nad lähtuvad valitsevast situatsioonist. Nende töötingimused on suures osas määratletud väliste tegurite poolt. Ravitsejad ravivad neid haigusi ja tõbesid, mis reaalselt eksisteerivad, ja Peter Ege ülevaatest ilmneb, et paljude tänapäeva haiguste põhjuseks on stress ja ebarahuldavad elamistingimused. Selliseid haigusi ei saa ravida füüsikaliste ega keemiliste vahenditega, need vajavad pigem psühholoogilist ja sotsiaalpoliitilist suunamist. "Ravi tähendab olla ja elada õnnelikult," kuulsin üht arsti lausuvat Kopenhaageni Ülikoolis sot- 
siaaltervishoiu loengus 1978. aasta aprillis. Kas pole tegemist erakordselt olulise väitega, kui soovitakse mõista, mida ravitsejad suudavad ja soovivad teha? Ravitsejate ravil puuduvad teaduslikud lähtekohad, Skandinaaviamaades aga kasvab pidevalt vajadus arstiabi järele ning rahalised investeeringud muutuvad riigikassale järjest kurnavamaks - üksikisik on aga ikkagi hätta jäetud. Heaolu ja nõustamist on mitmetel aladel vähendatud (vt Ege 1977: 64-69; Koefoed \& Nielsen 1978).

Sellisel pingeväljal jätkab rahvaravitseja oma igapäevast tööd. Kogu oma ebaseaduslikkuses esindab ta kõiki alates spekulandist, kes kasutab oma huvides ära teiste inimeste õnnetusi, kuni isikuni, kes ohverdab oma elu teiste eest.

Ühiskond hoiab tugevasti kinni tervisemüüdist ja seepärast on vaja ravitsejaid, isegi kui neist saavad ametlikult kurjategijad. Ravitsejad on ühiskondlikult vajalikud nii siis, kui nad toodavad heaolu ja tervist, kui ka siis, kui neid kasutatakse peksupoistena.

Ühiskonna kaitseventiili positsioon tähendab, et ravitsejad moodustavad sügavalt integreeritud rahvapärase institutsiooni, mida ei suuda välja juurida ükski võim.

Tõlkinud Piret Paal, toimetanud Maarja Villandi ja Tiina Sammelselg

\section{Kommentaar}

1 Tõlgitud väljaandest: Rørbye, Birgitte 1982. Ethnomedicine. Ethnologia Scandinavica: A Journal for Nordic Ethnology 12. Lund: Folklivsarkivet, lk 53-85.

\section{Kirjandus}

Alver, Bente Gullveig (koost) 1980. Botare: En bok om etnomedicin i Norden. NIF publications 8. Stockholm: LT:s förlag.

Alver, Bente Gullveig 1978. "Du skal gå frisk herfra": En etnomediciner og hans patientbehandling. Tradisjon: Tidsskrift for folkeminnevitskap 8, lk 27-36.

Arbejdsmiljø 1974 = Arbejdsmiljøgruppen af 1972: Arbejdsmiljøundersøgelsen . Rapport 2. København: Arbejdsmiljøgruppen. 
Arbejdsmiljø 1975 = Arbejdsmiljøgruppen af 1972:Arbejdsmiljø. Grænseværdier, arbejdstiden, meningsfuldt job, udstødningen. Rapport 3. København: Arbejdsmiljøgruppen.

Bang, Oluf Lundt 1852. Haandbog $i$ Therapien. København: Gyldendal.

Barnes, John A. 1954. Class and Committees in a Norwegian Island Parish. Human Relations 7: 1, lk 39-58.

Betænkning 594 = Betænkning vedrørende kvinders sundhedsforhold . København: Statsministeriet, Kommissionen vedrørende Kvinders Stilling i Samfundet 1971.

Betænkning $715=$ Betænkning vedrørende kvinders stilling $i$ samfundet. København: Statsministeriet, Kommissionen vedrørende Kvinders Stilling i Samfundet 1974.

Betænkning 809 = Prioritering $i$ Sundhedsvæsenet. Betænkning fra sundhedsprioriteringsudvalget. København: Indenrigsministeriet 1977.

Biering, Karsten 1973. Folkelig lægekunst på Løgstøregnen: Haaningslægten og dens behandlingsmetoder gennem ca. 100 år. Separaat väljaandest Folk og Kultur: Årbog for dansk etnologi og folkemindevidenskab. København: Foreningen Danmarks Folkeminder (sama on välja andnud ka Ferrosan).

Bø, Olav 1972. Folkemedisin og lærd medisin: Norsk medisinsk kvardag på 1800-talet. Oslo: Det Norske Samlaget.

Broch, Ole Jacob 1954. Lege eller kvaksalver: Medisinen, mennesket og samfunnet. Oslo: Cappelen.

Bygren. Lars Olov 1974. Met and Unmet Needs for Medical and Social Services. Scandinavian Joumal of Social Medicine, suppl. 8, lk 1-134.

Calais, Sonja 1963. Sjukdom, invaliditet och anpassning. Litsensiaadiväitekiri. Käsikiri Uppsala Ülikooli sotsioloogiaosakonnas. Uppsala: Uppsala Universitet.

Carøe, Kristian 1920. Jydske benbrudslæger. Samlinger til jydsk historie og topografi 4: 3, lk 425-503.

Christensen, Vagn 1976. Socialmedicinsk grundbog. København: Gyldendal.

Claësson, Bent H. \& Mundt, Inger \& Søe, Gunni 1974. Patientens bog: En krisebog for patienter og pårørende. København: Hans Reitzel.

Clausen, Frits 1936. Læge og kvaksalver: En kritisk Fremstilling af medicinske Vranglærer og Fejlveje. Bovrup: Eget Forlag.

Clements, Forrest E. 1932. Primitive Concepts of Disease. University of California Publications in American Archaeology and Ethnology 32: 2, lk 185-252.

Diderichsen, Birgitte 1977. Hvad indebærer en materialistisk sygdomsteori? Agger, Niels Peter \& Diderichsen, Birgitte et al. Terapi som politisk praksis: Radikale terapiformer og deres frigørende muligheder $i$ samfundet. København: Hans Reitzels Forlag.

Dødsårsagerne i Danmark 1970 \& 1973. København. 
Eagle, Robert 1980. A Guide to Alternative Medicine. London: British Broadcasting Corporation.

Ege, Peter 1977. Behandling. Heinild, Svend. De er syge, sagde lægen: Tilegnet Svend Heinild på hans 70-årsdag. København: Carit Andersen.

Fabrega, Horacio jun. 1972. The Study of Disease in Relation to Culture. Behavioral Science 17: 2, lk 183-203.

Femina 1973, nr 36.

Frøiland, Ø.et al.1976. Læge-patient-forholdet: En del av dagens folkmedisin. Tradisjon: Tidsskrift for folkeminnevitskap 6.

Giersing, Ove Malling 1861. Brystbetændelsers Forekomst og Behandling i privat Praxis. Bibliotek for Læger 2.

Goffman, Erving 1963. Stigma: Notes on the Management of Spoiled Identity. Spectrum book S-73. Englewood Cliffs (New Jersey): Prentice-Hall.

Gotfredsen, Edvard 1973. Medicinens historie. 3. tr. København: Nyt Nordisk Forlag.

Gregersen, Per \& Bech, Karine et al. 1976. Sygdom i samfundet. Fremads fokusbøger. København: Fremad.

Hansen, Hans Peter 1960-1961. Kloge folk: Folkemedicin og overtro i Vestjylland I-II. 2. tr. København: Rosenkilde og Bagger.

Henningsen, Gustav 1975. Hekseforfølgelser efter "hekseprocessernes tid". Folk og Kultur: Årbog for dansk etnologi og folkemindevidenskab. København: Foreningen Danmarks Folkeminder, lk 98-147.

Henningsen, Gustav 1978. Kloge folk og "Kloge Søren”. Henningsen, Gustav \& Nellemann, George (toim). Det farlige liv: Sygdom samfund og lægekunst. København: Nationalmuseet, lk 70-87.

Holst, Erik \& Scocozza, Lone 1972. Lægekontaktfrekvensen i socialmedicinsk belysning: Stikprøveundersøgelse blandt den voksne befolkning i Roskilde. Ugeskrift for Læger 22 = A sociomedical survey of doctor-patient contacts: Spot testing of the adult population of Roskilde, Denmark. Social science \& medicine 1973, September 7 (9), lk 729-743.

Honko, Lauri 1959. Krankheitsprojektile: Untersuchung über eine urtümliche Krankheitserklärung. Folklore Fellow Communications 178. Helsinki: Suomalainen Tiedeakatemia.

Honko, Lauri 1972. The Problem of Defining Myth. The Myth of the State: Based on Papers Read at the Symposium on the Myth of the State Held at Abo on the 6th-8th September, 1971. Scripta Instituti Donneriani Aboensis 6. Stockholm: Almqvist \& Wiksell, lk 7-19.

Honko, Lauri 1976. Riter: En klassifikation. Fataburen: Nordiska museets och Skansens årsbok. Stockholm: Nordiska museet, lk 71-84. 
Jansson, Peer 1977. Lægestanden som profession. Heinild, Svend. De er syge, sagde lægen: Tilegnet Svend Heinild på hans 70-årsdag. København: Carit Andersen.

Jeffers, James R. \& Bognanno, Mario F. \& Bartlett, John C.1971. On the Demand Versus Need för Medical Services and the Concept of 'Shortage'. American Journal of Public Health 61: 1 (jaanuar), lk 46-62.

Jensen, Anders Ottar \& Jensen, Hans Siggaard 1976. Medicinsk videnskabsteori. København: Ejlers.

Johansen, A. 1912. Uvidenskabelige helbredelsesmetoder. Jydsk Maanedsskrift.

Juul, Svend \& Sabroe, Svend 1977. Det danske sundhedsvæsen. Socialmedicinsk Institut, Udgivelse 16. Århus: Socialmedicinsk Institut.

Koefoed, O. P. S. \& Nielsen, H. 1978. Historiske og aktuelle tendenser $i$ den samfundsmæssige produktion af sygdom of sundhed. Käsikiri. København.

Koos, Earl Lomon 1954. The Health and Regionville: What the People Thought and Did about It. New York: Columbia University Press.

Lægeforeningens vejviser. 1976. København: Almindelige Danske Lægeforening.

Lærum, Ole Didrik 1976. Ulysses-syndromet - helseproblemer hos patienter med "non-disease". Nordisk Medicin: Medlemstidskrift för läkare i de nordiska läkarförbunden 91.

Larsen, J.-H. \& Nielsen, I. Lunde 1973. Lægers sociale baggrund, studieforløb og uddannelsesmål. Ugeskrift for Læger.

Leach, Edmund 1976. Culture \& Communication:The Logic by Which Symbols Are Connected: An Introduction to the Use of Structuralist Analysis in Aocial Anthropology. Themes in the social sciences. Cambridge: Cambridge University Press.

Levevilkår i Danmark 1976. Levevilkår i Danmark: Statistisk oversigt = Living conditions in Denmark: Compendium of Statistic. København: Socialforskningsinstitutet.

Lieban, Richard W. 1973. Medical Anthropology. Honigman, John Joseph (toim). Handbook of Social and Cultural Anthropology. Rand McNally anthropology series. Chicago: Rand McNally Co, lk 1031-1072.

Liedman, Sven-Eric 1975. Det vita skrået: Några notiser. Ord och Bild 6, lk 313-317.

Matthiessen, Carl Christian 1967. Skuddet i dansk sygdomstro: Med et tillæg om den ætiologiske diagnose. Danmarks folkeminder 77. København: Akademisk Forlag.

Møller, Jens Schou 1942. Om kvaksalveri og Kvaksalvere. København: Steen Hasselbalchs Forlag.

Munkebo, Jørgen \& Olesen, Erik Palle 1971. Helbredelse - ved ikke-autoriserede metoder: Bed. København: Thaning \& Appel.

Münster, E. 1977. Sådan arbejder brevkasselægen. Sandoz Tidskrift 2. 
Noltenius, J. 1976. Et liv før døden - status over dansk folkesundhed. Information 6.8.

Nørrelund, Niels 1977. En praktiserende læges betragtninger. Dyhre, Bodil (toim). Patient, sygeplejerske, læge: Hvis behov? København: Hans Reitzel.

Observa 1971 = Indstillingen til ikke-autoriserede helbredere. Institut for erhversanalyser og markedsforskning. Marts 1971.

Piø, Iørn 1978. Om naturlæger: Et personligt synspunkt. Henningsen, Gustav \& Nellemann, George (toim). Det farlige liv: Sygdom samfund og lægekunst. København: Nationalmuseet.

Riisgård, Knud \& Weiss, Walter 1978. Pensionisten, terapeuten og samfundet: En bog om holdninger $i$ omsorg. Socialpædagogisk bibliotek. København: Munksgaard.

Romains, Jules 1924. Théatre de Jules Romains 1: Knock ou Le triomphe de la medicine: Comédie en trois actes. Éditions de la nouvelle revue française. Paris: Gallimard.

Rørbye, Birgitte 1970. Mediaforskning og traditionsforskning: Et studium af ugebladsnoveller med kærlighedstema. Studier af de nordiske landes kulturelle og æstetiske liv: Forskningsprojekt: Delprojekt 3: Undersøgelse 3. København: Institut for folkemindevidenskab.

Rørbye, Birgitte 1974. Fællesnordisk undersøgelse af ugeblade. Hansson, Gunnar \& Fredholm, Arne (toim). Litteratur och teater. Nordisk Sommeruniversitet: Studier av de nordiske landes estetiske och kulturelle liv 3, København: Akademisk Forlag \& Lund: Studentlitteratur.

Rørbye, Birgitte 1976a. Kloge folk og skidtfolk: Kvaksalveriets epoke i Danmark. København: Politikens Forlag.

Rørbye, Birgitte 1976b. Den illegale sygdomsbehandling som folkloristisk problem: Bidrag til en socio-kulturel oversikt for Danmark. Fataburen: Nordiska museets och Skansens årsbok. Stockholm: Nordiska museet.

Rørbye, Birgitte 1978a. Nutidige folkemedicin. UNIFOL: Årsberetning. København: Institut for Folkloristik, Københavns Universitet = Tradisjon: Tidsskrift for folkeminnevitskap 1978.

Rørbye, Birgitte 1978b. Folketroen som begreb og forskningsfelt. Norveg: Tidsskrift for folkelivsgranskning 21.

Roth, Julius A. 1963. Timetables: Structuring the Passage of Time in Hospital Treatment and Other Careers. Indianapolis: Bobbs-Merrill.

Sand, Knud 1930. Om kvaksalveri. Goll, August \& Jacobsen, Hartvig (koost). Forhandlingerne paa Dansk Kriminalistforenings treogtyvende Aarsmøde den 24. og 25. Februar 1930. København: Dansk Kriminalistforenings = Ugeskrift for Læger 92: 5051, lk 1176-1183 \& 1207-1213.

Schneider, David M. 1947. The Social Dynamics of Physical Disability in Army Basic Training. Psychiatry 10, lk 323-333. 
Sydow, Carl Wilhelm von 1931. Om folkets sägner. Liestøl, Knut \& Sydow, Carl Wilhelm von (toim). Folkevisor. Folksägner och folksagor = Folkeviser. Folkesagn og Folkeeventyr. Nordisk kultur 9. Oslo: Aschehoug\& København: Schultz, lk 96-112.

Zachau-Christiansen, Birgit 1977. Socialpædiatriens fremtid. Heinild, Svend. De er syge, sagde lægen: Tilegnet Svend Heinild på hans 70-årsdag. København: Carit Andersen.

Thyssen, Ole 1977. Den ulykkelige bevidsthed:. Om begrebet savn. København: Gyldendal.

Tillhagen, Carl-Herman 1958. Folklig läkekonst. Stockholm: Nordiska museet.

Turner, Victor W. 1969. The Ritual Process: Structure and Antistructure. The Lewis Henry Morgan lectures. London: Routledge \& Kegan Paul.

Ude og Hjemme 1973, nr 35.

Voss, Tage 1977. Lægen - den bekitlede ludder. Heinild, Svend. De er syge, sagde lægen: Tilegnet Svend Heinild på hans 70-årsdag. København: Carit Andersen.

White, Kerr \& Williams, T. Franklin \& Greenberg, Bernard G. 1961. The Ecology of Medical Care. New England Journal of Medicine 265, lk 885-892.

WHO 1946 = Constitution of the World Health Organization: Signed at the International Health Conference New York 22 July 1946. Geneva: World Health Organization.

Wolf, Eric R. 1973. Bønder: En socialantropologisk oversigt over bondesamfundets udvikling. København: Hans Reitzel.

\section{Summary}

\section{Ethnomedicine}

\section{Birgitte Rørbye}

Key words: health care, ethnomedicine, conception of disease, illness behaviour, tale of disease, patient, folk healers, folk tales, health myth

Research in ethnomedicine involves the observance of the views, principles, and behaviour regarding illnesses and diseases by different people and cultures. The activities of folk healers and turning to them for help are still topical, even though the awareness of people has grown and the level of education is considerably higher than in the past. Nevertheless, it appears that regardless of the availability of medical care, there are always patients who turn only to folk healers. Another group of people who tend to turn to folk healers for help are those whose treatment by medical professionals has not been successful. In folklore the theme is represented by tales of diseases and illnesses, in which the main characters are a positive or negative patient and a positive 
or negative healer. These often stereotypical folktales are almost the only material that enables drawing conclusions on the illness behaviour of the customers of folk healers. The reason behind all that is that the society is steadfastly fixated on the health myth.

Source: Rørbye, Birgitte 1982. Ethnomedicine. Ethnologia Scandinavica: A Journal for Nordic Ethnology, vol. 12. Lund: Folklivsarkivet, pp. 53-85. 